\title{
Towards a Complete Bibliography of V. M. Zhivov
}

\author{
Ernest A. Zitser \\ Duke University \\ ernest.zitser@duke.edu
}

\begin{abstract}
:
Составление полной библиографии научных работ В.М. Живова - это масштабное предприятие, которое, несомненно, потребует совместных усилий библиотекарей и ученых, представляющих множество различных стран и академических дисциплин. Библиография, помещаемая ниже, призвана лишь представить некоторые дополнения и исправления к “Списку научных трудов Виктора Марковича Живова," опубликованному в Веренице литер (2006) и довести этот список до настоящего времени. Включение дополнительных публикаций-как перепечаток и переводов, так $и$ оригинальных научных работ-будет полезно для будущих исследователей, особенно интересующихся направлением развития идей Живова, их влиянием и каналами их распространения. По той же причине, настоящая библиография также включает ссылки на интервью и публичные лекции Живова и его выступления на радио и телевидении, в том числе те, которые в настоящее время доступны только в Интернете. Хотя включение таких работ, как правило, размывает традиционные границы между академическими и научно-популярными публикациями, оно иллюстрирует характер современного информационного ландшафта u позволяет документировать деятельность Живова как публичного интеллектуала. Библиография, не учитывающая эти аспекты, не может претендовать на полное и достоверное отражение трудов $и$ дней Виктора Марковича Живова.
\end{abstract}

Keywords:

V. M. Zhivov; bibliography; Slavic languages and literatures; Slavic linguistics; Russian history; semiotics

Considering the immense scholarly output of V. M. Zhivov (1945-2013), the different venues in which it has appeared, and the numerous languages into which it has been translated, it hardly comes as a surprise that there is still no definitive bibliography of his works. In 2006, the editors of Вереница литер (hereafter $V L$ ) - a festschrift which was timed to coincide with the honoree's sixtieth birthday and named after a line of verse from one of his favorite poets (Joseph Brodsky) - compiled a "list of the scholarly works of Viktor Markovich Zhivov." At the time of publication, this impressive list was the most complete bibliography of Zhivov's oeuvre. And despite a recent attempt to update the

1 “Список научных трудов Виктора Марковича Живова," in Вереница литер: С6. статей к 6о-летию В. M. Живова, отв. ред. А. М. Молдован (Studia philologica) (Москва: ИРЯ РАН; Языки славянской культуры, 2006), 607-623, available online at Danefae.org (Москва, 2009-2011), URL: http://danefae.org/pprs/zhivovz/biblio.htm. Although the compiler(s) of this list of scholarly publications remain unidentified, Zhivov's bibliography appears to be the work of the volume's editors, possibly with the cooperation of the festschrift dedicatee himself. The festschrift's title refers to a line from verse VIII (verse $\mathrm{V}$ in the English translation) of Brodsky's "Римские элегии" (1981): "Jig, little candle tongue, over the empty paper, // bow to the rotten breath as though you were courted, // follow-but don't get too close!- the pauper // letters standing in line to obtain the content." See Joseph Brodsky, "Roman Elegies," in Collected Poems in English; poems written in English and poems translated from the original Russian by or with the author; including translations by Jonathan Aaron ... [et al.]; edited by Ann Kjellberg (New York: Farrar, Straus and Giroux, 2000), 274-28o (poem), 521-522 (notes), here 276. 
2006 compilation, ${ }^{2}$ it remains so to this very day. However, since Viktor Markovich continued to conduct research until the very end of his life, ${ }^{3}$ which was cut short just eight years after the celebration of his sexedecennial, the 206-item bibliography at the end of $V L$ no longer reflects the full extent of his published writings.

Compiling a complete bibliography of the works of V. M. Zhivov is a massive undertaking that will undoubtedly require the collaborative efforts of librarians and scholars from many countries and numerous academic disciplines. My own contribution to the daunting task of documenting the "long tail" ${ }^{4}$ of Zhivov's publications is necessarily much more modest. In the bibliography that follows, I seek to make some additions and corrections to VL's "List of Scholarly Works" and to bring this list of publications from 2006 up to the present. By inserting a few more entries into the "queue of inscriptions" still awaiting interpretation, I hope to make a small contribution to the process of "endless semiosis," ${ }^{5}$ and thereby to pay my respects to the memory of a remarkable human being, mentor, and colleague, whose writing continues to serve as a source of inspiration for scholars from around the world.

\section{Part I: Addenda and Corrigenda to "A List of Scholarly Works of Viktor Markovich Zhivov" (1967-2006)}

The first 206 entries in the following bibliography comprise a slightly-revised version of the "list of scholarly works" published in Вереница литер. In the case of each of the entries listed in Part I, I have retained the chronological order and the citation style originally adopted by the festschrift's editors. For ease of reference, however, I have numbered each of the individual bibliographic items in the list and, whenever possible, added links to any freely-accessible, online publications of the work described. Annual entries will be cited hereafter by the abbreviated title and page number of the 2006

\footnotetext{
2 Дмитрий Сичинава, comp., “В. М. Живов: Избранная библиография,” Новое литературное обозрение 125:1 (2014), URL: http://www.nlobooks.ru/node/4511. As the compiler of this "selective bibliography" noted, his primary task was merely to provide full citations for all the works explicitly mentioned in the article of his two senior colleagues at the Vinogradov Institute of Russian Language. C. A. Иванов and А. М. Молдован, “Талант, ответственность и радость жизни,” Новое литературное обозрение 125:1 (2014), URL: http://www.nlobnooks.ru/node/4505.

${ }^{3}$ Despite his final illness, V. M. Zhivov managed to complete what he considered to be his "life's work": "a fundamental monograph about the language of Russian literary texts” (фундаментальная монография о языке русской письменности), entitled История русского литературного языка. The Vinogradov Institute of Russian Language is currently preparing a posthumous edition of this work. Sее Институт русского языка им. В. В. Виноградова РAH, “Виктор Маркович Живов," URL: www.ruslang.ru/doc/zhivov.pdf; А. М. Молдован, “Виктор Маркович Живов,” Газета «Троицкий вариант-Наука», № 127 (23 April 2013), 15, available online at: http://trv-science.ru/2013/04/23/viktormarkovich-zhivov/; Ivanov and Moldovan, "Талант, ответственность и радость жизни."

4 Chris Anderson, “The long tail," Wired Magazine, Issue 12:10 (October 2004), URL: http://www.wired.com/wired/archive/12.10/tail.html .

${ }^{5}$ T.L. Short, Peirce's Theory of Signs (Cambridge: Cambridge University Press, 2007), 53-59; Albert Atkin, "Peirce's Theory of Signs," in The Stanford Encyclopedia of Philosophy (Summer 2013 Edition), ed. Edward N. Zalta, available at URL: http://plato.stanford.edu/archives/sum2013/entries/peirce-semiotics/.
} 
festschrift ( $V L)$, followed by the number (in parentheses) that I have assigned to each individual bibliographic entry.

Addenda and corrigenda to the 2006 list of publications-in most cases, revised reprints and translations of Zhivov's scholarly work-can be found in the footnotes to individual entries. It is my belief that the inclusion of these publications will be useful for future researchers, especially those who would seek to assess the vector and impact of Zhivov's ideas by tracing the networks through which they circulated. For the same reason, the present bibliography also incorporates references to Zhivov's personal interviews, public lectures, and television- and radio-appearances, including those that are currently available only on the Internet. Although such a move tends to blur the traditional distinctions between scholarly and popular publications, it serves to demonstrate the varied nature of today's information landscape and helps to document Zhivov's activity as a public intellectual. A bibliography that fails to take these aspects into account cannot possibly hope to provide a complete and accurate re-presentation of Zhivov's life and times.

\section{7}

1. Опыт анализа сложных существительных русского языка // Материалы XXII науч. студ. конф. - Тарту, 1967. — С. 142-147.

2. Соотношение некоторых интуитивных семантических критериев // Третья межвуз. студ. конф. по проблемам структурной и прикладной лингвистики. - M., 1967. - C. 11-13.

1971

3. Типология сочетаний согласных в русских говорах // Вопр. языкознания. — 1971. 一№ 2. 一С. 69-82.

1972

4. Залог // Большая советская энциклопедия. - Т. 9. - М., 1972. - С. $315 .{ }^{6}$

5. Тавтология // Краткая литературная энциклопедия. - Т. 7. - М., 1972. - С. $326 .^{7}$

6. Д. И. Ушаков // Краткая литературная энциклопедия. - Т. 7. - M, 1972. C. $860^{8}$

7. Условные языки // Краткая литературная энциклопедия. - Т. 7. - М., 1972. - С. $841-842 .-$ В соавт. с Т. В. Венцель. ${ }^{9}$

1973

\footnotetext{
${ }^{6}$ Available online at: http://slovari.yandex.ru/ книги/БСЭ/Залог (грамматич.)/

${ }^{7}$ Available online at: http://feb-web.ru/feb/kle/kle-abc/ke7/ke7-3262.htm

${ }^{8}$ Available online at: http://feb-web.ru/feb/kle/kle-abc/ke7/ke7-86or.htm

${ }^{9}$ Available online at: $\underline{\text { http://feb-web.ru/feb/kle/kle-abc/ke7/ke7-8413.htm }}$
} 
8. «Август четырнадцатого» и русское историческое самосознание // Август четырнадцатого читают на Родине: Сб. ст. и отзывов. - Париж, 1973.- С. 83-99. - Под псевд. И. Тропинин.

9. Проблемы синтагматической фонетики в свете типологии языков // Проблемы теоретической и прикладной фонетики и обучения произношению. - М., 1973. - С. 20-23.

10. Сакральные образы в русской поэзии // Сб. ст. по вторичным моделирующим системам. - Тарту, 1973. - С. 76-85.

$[608]$

11. Типологические заметки // Лингво-типгологические исследования. - Ч. 1. - M., 1973. - C. 240-249.

12. Центр и периферия в фонологической организации слова // Лингвотипологические исследования. - Ч. 1. - М., 1973. - С. 80-163.

13. Канцеляризмы // Большая советская энциклопедия. - Т. 11. - М., 1973. С. $341 .-$ Б. п. ${ }^{10}$

14. Клише // Большая советская энциклопедия. - Т. 12. - М., 1973. - С. 320. ${ }^{11}$

15. Криптография //Большая советская энциклопедия.-Т. 13. - M, 1973. - С. $434 .^{12}$

16. Кульминативная функция // Большая советская энциклопедия. - Т. 13. М., 1973. - С. 592. -Б. п. ${ }^{13}$

17. П. А. Лавров // Большая советская энциклопедия. - Т. 14. - М., 1973. - С. 91. - Б. п. ${ }^{14}$

18. В. И. Чернышев // Краткая литературная энциклопедия. - Т. 8. - М., 1973. - C. $464 .^{15}$

19. Центр и периферия в языке в свете языковых универсалий // Вопр. языкознания. - 1973. - № 5. - С. 24-35. - В соавт. с Б. А. Успенским.

1974

20. Опыт формального членения новеллы // Материалы всесоюз. симпозиума по вторичным моделирующим системам, I. - Тарту, 1974. - С. 201-209.

21. Проблемы синтагматической фонологии в свете фонетической типологии языков // Вопр. языкознания. —1974. — № 4. - С. 57-70.

${ }^{10}$ Available online at: http://slovari.yandex.ru/ книги/БСЭ/Канцеляризмы/

${ }^{11}$ Available online at: http://slovari.yandex.ru/ книги/БСЭ/Клише (штамп)/

${ }^{12}$ Available online at: http://slovari.yandex.ru/ книги/БСЭ/Криптография/

${ }^{13}$ Available online at: $\underline{\mathrm{http}} / / /$ slovari.yandex.ru/ книги/БСЭ/Кульминативная функция/

${ }^{14}$ Available online at: http://slovari.yandex.ru/ книги/БСЭ/Лавров Петр Алексеевич/

${ }^{15}$ Available online at: http://feb-web.ru/feb/kle/kle-abc/ke8/ke8-4641.htm 
22. В. Матезиус // Большая советская энциклопедия. - Т. 15. - M, 1974. - С. $467 .^{16}$

23. Междометие // Большая советская энциклопедия. - Т. 15. - М., 1974. - С. 591. - Б. п. ${ }^{17}$

24. Метатеза // Большая советская энциклопедия. - Т. 16. - М., 1974. - С. $144 .^{18}$

25. Наклонение // Большая советская энциклопедия. - Т. 17. - М., 1974. - С. 222. - Б. п. ${ }^{19}$

26. Наречие // Большая советская энциклопедия. — Т. 17. - М., 1974. — С. $250 .^{20}$

27. Местоимение // Большая советская энциклопедия. - Т. 16. - М., 1974. - С. 109-110. - В соавт. с Е. В. Падучевой. ${ }^{21}$

1975

28. Иерархические отношения согласных в синтагматике // Лингвотипологические исследования. - Ч. 2. - М., 1975. - С. 70-149.

29. Первый всесоюзный симпозиум по вторичным моделирующим системам // Русская филология: Сб. студ. работ. - Тарту, 1975. - С. 123-151. — В соавт. с М. Ю. Лотманом и др. ${ }^{22}$

[6o9]

30. Типологические аспекты диглоссии // Soomi-Ugri rahvad ja idamaad. Orientalistikakabineti teaduslik konverents 12-14.XI.1975. - Tartu, 1975.—C. 77-83. - В соавт. с Б. А. Успенским.

31. L'Opposition entre le centre et la peripherie et les universaux linguistiques // Proceedings of the 11th International Congress of Linguists. - Vol. II.- Bologna, 1975. - Р. 257-267. - В соавт. с Б. А. Успенским. ${ }^{23}$

\footnotetext{
${ }^{16}$ Available online at: http://slovari.yandex.ru/ Книги/БСЭ/Матезиус Вилем/

${ }^{17}$ Available online at: http://slovari.yandex.ru/ книги/БСЭ/Междометие/

${ }^{18}$ Available online at: http://slovari.yandex.ru/ книги/БСЭ/Метатеза/

${ }^{19}$ Available online at: http://slovari.yandex.ru/ книги/БСЭ/Наклонение (грамматич. категория глагола)/

${ }^{20}$ Available online at: http://slovari.yandex.ru/ книги/БСЭ/Наречие (часть речи)/

${ }^{21}$ Available online at: http://slovari.yandex.ru/ книги/БСЭ/Местоимение/

${ }^{22}$ Отв. ред. Х. Пак, В. Беззубов. The other со-authors include I. Paperno and G. Levinton. Sеe "Сборники трудов Студенческого научного общества," in Труды по русской литературе и семиотике Тартуского Университета 1958-1990. Указатели содержания (Тарту, 1991), URL:

http://www.ruthenia.ru/document/437761.html\#59.9

${ }^{23}$ French translation of VL 608 (no. 19). Corrigendum: Luigi Heilmann, ed., Proceedings of the 11th International Congress of Linguists, Bologna-Florence, Aug. 2-Sept. 2, 1972 (Bologna: Società editrice il Mulino, 1974). Since the actual date of publication is 1974 , this entry should be listed under the previous year.
} 


\section{6}

32. Универсалии синтагматического функционирования признака звонкости. - М., 1976. - 36 с. - (Предв. публ. Ин-та рус. яз. АН СССР; Вып. 89).

33. Конечные невзорванные смычные в силлабических языках // Тез. дискуссии «Типология как раздел языкознания». - М., 1976. - С. 79-82.

34. Степени сравнения // Большая советская энциклопедия. - Т. 24. - М., 1976.- С. 490. -Б. п. ${ }^{24}$

35. Существительное // Большая советская энциклопедия. - Т. 25. - М., 1976. - C. $110-111 .^{25}$

36. Sprachbeschreibung und sprachliche Universalien // Theoretische Linguistik in Osteuropa. - Tübingen, 1976. - S. 140-162. - В соавт. с Б. А. Успенским. ${ }^{26}$

37. [Рец. на ст.:] Н. Т. Войтович. К вопросу о путях развития аканья в восточнославянских языках //Russian Linguistics. Vol. 3 (1976). — № 4. - C. $334-335$.

\section{7}

38. Типологический анализ синтагматического функционирования признака звонкости: Автореф. дис. ... канд. филол, наук. - М., 1977. - 28 с.

39. Флексия // Большая советская энциклопедия. - Т. 27. - М., 1977. - С. 490. — Б. п. ${ }^{27}$

40. Формообразование // Большая советская энциклопедия. - Т. 27. - М., 1977. - C. $548 .^{28}$

41. Форма слова // Большая советская энциклопедия. - Т. 27. - М., 1977. - С. 540. - Б. п. ${ }^{29}$

42. Форматив // Большая советская энциклопедия. - Т. 27. - М., 1977. - С. 542. - Б. п. ${ }^{30}$

43. Une procédure de classification des consonnes destinée à la description de leurs combinaisons // Computational and Mathematical Linguistics: Proceedings of the International Conference on Computational Linguistics. Pisa, 1973. - Firenze, 1977. - P. 235-253.

44. Centre-Periphery Opposition and Language Universals // Linguistics. — 1977. № 196. - P. 5-24. - В соавт. с Б. А. Успенским. ${ }^{31}$

${ }^{24}$ Available online at: http://slovari.yandex.ru/ книги/БСЭ/Степени сравнения/

${ }^{25}$ Available online at: http://slovari.yandex.ru/ книги/БСЭ/Существительное/

${ }^{26}$ Trans. by W. Jachnow for Konzepte der Sprach- und Literaturwissenschaft, Bd. 18, ed. by Wolfgang Girke.

${ }^{27}$ Available online at: http://slovari.yandex.ru/ книги/БСЭ/Флексия/

${ }^{28}$ Available online at: http://slovari.yandex.ru/ книги/БСЭ/Формообразование (грамматич.)/

${ }^{29}$ Available online at: http://slovari.yandex.ru/ книги/БСЭ/Форма слова/

${ }^{30}$ Available online at: http://slovari.yandex.ru/ книги/БСЭ/Форматив/

${ }^{31}$ English translation of $V L 608$ (no. 19). 
1978

45. Фрикативные согласные // Большая советская энциклопедия. - Т. 28. М., 1978. - C. $96 .-$ Б. п. ${ }^{32}$

46. Фузия // Большая советская энциклопедия. - Т. 28. - М., 1978. - С. 121. Б. п. ${ }^{33}$

47. Части речи // Большая советская энциклопедия. - Т. 29. - М., 1978. — С. $30-31 .^{34}$

48. Ютоацтекские языки // Большая советская энциклопедия. - Т. зо. - М., 1978. - C. $423-124 . .^{35}$

49. Pitch Accent Systems Versus Restricted Tone Systems // Estonian Papers in Phonetics. - Tallinn, 1978. - P. 99-101.

50. Some Typological Observations Concerning Noun Compounds // Linguistics. 1978. — № 208. — P. 5- 12.

51. О старообрядчестве (по поводу статьи о. Александра Шмемана) // Вестник русского христианского движения. — 1978. — № 125. - С. 98-107. - В соавт. с Б. А. Успенским; под псевд. Н. H. ${ }^{36}$

1979

52. О внутренней и внешней позиции при изучении моделирующих систем // Вторичные моделирующие системы. - Тарту, 1979. - С. 6-14.

53. О старообрядчестве (к продолжению полемики) // Вестник русского христианского движения. -1979. — № 128. - С. 98-107. - В соавт. с Б. А. Успенским; под псевд. H. $H^{37}$

54. [Рец. на кн.:] Comrie B. and Stone G. The Russian Language Since the Revolution. Oxford, 1978 // Russian Linguistics. — Vol. 5 (1980). — № 2. — P. 181— $190 .^{38}$

1980

55. Очерки по синтагматической фонологии. - М.: Изд-во МГУ, 1980. - 256 c. ${ }^{39}$

1981

${ }^{32}$ Available online at: http://slovari.yandex.ru/ книги/БСЭ/Фрикативные согласные/

${ }^{33}$ Available online at: http://slovari.yandex.ru/ книги/БСЭ/Фузия (лингвистич.)/

${ }^{34}$ Available online at: http://slovari.yandex.ru/ книги/БСЭ/Части речи/

${ }^{35}$ Available online at: http://slovari.yandex.ru/ книги/БСЭ/Юто-ацтекские языки/

${ }^{36}$ Available online at: http://www.rp-net.ru/book/vestnik/

${ }^{37}$ Corrigendum: the correct pagination is $88-96$. Available online at: http://www.rp-net.ru/book/vestnik/

$3^{38}$ Corrigendum: since this review appeared in the December 1980 issue of Russian Linguistics, it should be placed under the entry for the following year.

39 The book's introduction (Введение), entitled “Признак звонкости”, С. 5-30, is available online at: http://danefae.org/djvu/\#Zh 
56. Кощунственная поэзия в системе русской культуры конца XVIII - начала XIX века // Семиотика культуры: Тр. по знаковым системам. Вып. 13. - Тарту, 1981. - С. 56-91. - (Учен. зап. / Тартуский гос. ун-т; Вып. 546).

57. Описание языка и языковые универсалии // Теоретические и прикладные аспекты вычислительной лингвистики. - М., 1981. - С. 3-28. - В соавт. с Б. А. Успенским. ${ }^{40}$

[611]

58. [Рец. на сб.:] Русские говоры. М., 1975 // Russian Linguistics.—Vol. 6 (1981). — № 1. - P. 151-161.

59. [Рец. на сб.:] Russian Orthodoxy under the Old Regime. Minneapolis, 1978 // Ostkirchliche Studien. 1981. - Bd. 31, Hft 2/3. - S. 188-195.

1982

6o. «Мистагогия» Максима Исповедника и развитие византийской теории образа // Художественный язык средневековья. - М., 1982. - С. 108-127. ${ }^{41}$

61. Margeretiana renovata: Исправления и дополнения к ст. Д. С. Ворта «Тhe French Captain's Russian» // Russian Linguistics.—Vol. 6 (1982).— № 3. - C 335351.

62. Влияние и система культуры: проблема традиций в иконоборческих спорах // Finitis duodecim lustris: Сб. ст. к бо-летию проф. Ю. М. Лотмана. - Таллин, 1982. -C. 66-69.

1983

63. Выдающийся вклад в изучение русского языка XVII века: О кн. G. Kotošixin. O Rossii v carstvovanije Alekseja Mixajlovčia / Ed. by A. E. Pennington. Oxford, 1980 // International Journal of Slavic Linguistics and Poetics. — Vol. 28 (1983). Р. 149-180. - В соавт. с Б. А. Успенским.

64. Zur Spezifik des Barock in Russland. Das Verfahren der Äquivokation in der russischen Poesie des 18. Jahrhunderts // Slavische Barockliteratur: Gedankschrift für Dmitrij Tschižewskij / Hrsg. von R. Lachmann. — München, 1983.- S. 25—56. - В соавт. с Б. А. Успенским.

1984

65. Лингвистическое благочестие в первой половине XIX века: Из истории размножения литературных языков в послепетровскую эпоху // Festschrift für Gerta Hüttl-Folter zum sechzigsten Geburtstag. - Wien, 1984. - S. 363-395. (Wiener Slavistisches Almanach; Bd. 13).

\footnotetext{
${ }^{40}$ Russian version of $V L 609$ (no. 36).

${ }^{41}$ For the English translation, see VL 613 (no. 84); for the Czech translation, see infra, Part II, no. 314.
} 
66. Правила и произношение в русском церковнославянском правописании XI-XIII века // Russian Linguistics. - Vol. 8 (1984). — № 3. - C. 251-293.

67. Семиотика // Энциклопедический словарь юного филолога. - M., 1984.C. $265-269$.

68. Универсалии // Энциклопедический словарь юного филолога. - M., 1984. - С. 315-317.

69. Метаморфозы античного язычества в истории русской культуры XVIIXVIII вв. // Античность и культура в искусстве последующих веков. -

[612]

М., 1984. - С. 204-285. - (Гос. музей изобразительных искусств.

Материалы науч. конф. 1982). - В соавт. с Б. А. Успенским.

70. Оппозиция рефлексов *е и *е̌ в книжном произношении и историческая диалектология // Совещание по вопросам диалектологии и истории языка (лингвогеография на современном этапе и проблемы межуровнего взаимодействия в истории языка). Ужгород, 18-2о сентября 1984 г.: Тез. докл. и сообщ. - М., 1984. - Т. 2. - С. 217-218. - В соавт. с Б. А. Успенским. 1985

71. Язык Феофана Прокоповича и роль гибридных вариантов церковнославянского в истории славянских литературных языков // Сов. славяноведение. -1985. - № 3. - С. 70-85.

72. [Рец. на кн.:] Feofan Prokopovič. De arte rhetorica libri X / Hrsg. von R. Lachmann. Köln; Wien, 1982 // Изв. АН СССР. Сер. лит. и яз. - 1985. - Т. 44, № 3. - C. $274-278$.

$$
1986^{42}
$$

73. Азбучная реформа Петра I как семиотическое преобразование // Труды по знаковым системам. - Вып. 19. - Тарту, 1986. - С. 54-67. - (Учен. зап.

Тартуского гос. ун-та; Вып. 720). Issue available online at: http://dspace.utlib.ee/dspace/handle/10062/25250?show=full

74. Еще раз о правописании ц и ч в древних новгородских рукописях // Russian Linguistics. - Vol. 10 (1986). № 3. - C. 291-306.

75. Новые материалы для истории перевода «Географии генеральной» Бернарда Варения // Изв. АН СССР. Сер. лит. и яз. - 1986. - Т. 45, № 3. - С. 246-260.

76. Славянские грамматические сочинения как лингвистический источник: О кн. D. S. Worth. The Origins of Russian Grammar: Notes on the State of Russian

${ }^{42}$ Addendum: [Составители К.В. Горшкова, Б.А. Успенский, Г.А. Хабургаев, В.М. Живов], Программа дисциплины «История русского языка». Для государственных университетов. Специальность 20о1: Русский язык и литература (М: Изд-во МГУ, 1986). 
Philology before the Advent of Printed Grammars. Columbus, 1983 // Russian Linguistics. — Vol. 10 (1986). № 1. - C $73-113$.

77. Богатство русского языка в концепции Ломоносова, его современников и последователей // М. В. Ломоносов и русская культура: Тез. докл. конф., посвящ. 275-летию со дня рожд. М. В. Ломоносова. - Тарту, 1986. - С. 79$82 .{ }^{43}$

78. [Выступления по докладам П. Филковой и К. Зеемана] // IX Междунар. съезд славистов. Киев, сентябрь 1983 г.: Материалы дискуссии. Языкознание. - Киев, 1986. - С. 53-54, 77.

79. History // Encyclopedic Dictionary of Semiotics / Ed. by T. A. Sebeok. Berlin; N. Y.; Amsterdam, 1986. - T. 1. - P. 309-311.

[613]

8o. Structural Linguistics and Semiotics // Encyclopedic Dictionary of Semiotics / Ed. by T. A. Sebeok. Berlin; N. Y.; Amsterdam, 1986. — Vol. 2. - P. 984-986.

81. Špet, Gustav Gustavovič // Encyclopedic Dictionary of Semiotics / Ed. by T. A. Sebeok. Berlin; N. Y.; Amsterdam, 1986. — T. 2. - P. 971-972.

82. Grammatica sub specie theologiae: Претеритные формы глагола быти в русском языковом сознании XVI-XVIII веков // Russian Linguistics. - Vol. 10 (1986). № 3. - С. 259-279. - В соавт. с Б. А. Успенским.

\section{7}

83. Проблемы формирования русского извода церковнославянского языка на начальном этапе // Вопр. языкознания. — 1987. — № 1. - С. 46-65. ${ }^{44}$

84. The Mystagogia of Maximus the Confessor and the Development of the Byzantine Theory of Image // St. Vladimir's Theological Quarterly. — Vol. 31 (1987). — № 4. - P. 349-376. ${ }^{45}$

85. Ц Царь и Бог: Семиотические аспекты сакрализации монарха в России // Языки культуры и проблема переводимости. - М., 1987. - С. 47-153. - В соавт. с Б. А. Успенским. ${ }^{46}$

\footnotetext{
${ }^{43}$ Отв. ред. М. Б. Плюханова. Sее “Сборники статей и тезисы научных конференций,” in Труды по русской литературе и семиотике Тартуского Университета 1958-199о. Указатели содержания (Тарту, 1991), URL: http://www.ruthenia.ru/document/437764.html\#76.23.

${ }^{44}$ Corrigendum: The correct title is "Проблемы формирования русской редакции церковнославянского языка на начальном этапе (По поводу книги И. Тота Русская редакция древнеболгарского языка $в$ конце XI-начале XII вв. София, 1985. 358 с.)," Вопросы языкознания 1 (1987): 46-65.

${ }^{45}$ Expanded, English-language translation of $V L 611$ (no. 6о). Sеe “Библиографическая справка," in В. М. Живов, Разыскания в обасти истории и предыстории русской культуры (Язык, семиотика, культура) (Москва: Языки славянской культуры, 2002) 730-732, here 730.

${ }^{46}$ For the Polish-language translation, see infra, Part I, addendum under the year 1992; for the Englishlanguage translation, see infra, Part II, no. 304.
} 
86. Zur Problematik und Spezifik des russischen Klassizismus: die Oden des Vasilij Majkov // Zeitschrift für slavische Philologie. — Bd. XLVII (1987), Hft 2. - S. 234-288. - В соавт. с И. Кляйном.

1988

87. История русского права как лингво-семиотическая проблема // Semiotics and the History of Culture: In Honor of Jury Lotman. - Columbus, Ohio, 1988. C $46-128 .{ }^{47}$

88. Роль русского церковнославянского в истории славянских литературных языков // Актуальные проблемы славянского языкознания. - M., 1988. - С. $49-98 .^{48}$

89. Смена норм в истории русского литературного языка XVIII века // Russian Linguistics. - Vol. 12 (1988). — № 1. - C. 3-7.

9o. Логика как проблема истории. I-II // Семиотика культуры: Тез. докл. всесоюз. школы-семинара по семиотике культуры. 8-18 сентября 1988, Архангельск. - Архангельск, 1988. - С. 13-18.

91. Актуальные проблемы истории русской риторической традиции (по поводу издания поэтики Ф. Кветницкого) // Сов. славяноведение. - 1988. № 2. - С. 94-99.

92. Вехи русской духовности: вершины и надрывы // Символ. - Вып. 20. Париж, 1988.-С. 10-17.

[614]

93. Выступление в ходе круглого стола, посвященного 10оо-летию Крещения Руси // Сов. славяноведение. - 1988. — № 6. - С. 36-39.

94. Иконоборческие споры и мнемотехническая традиция античной школы // Семиотика культуры: Тез. докл. всесоюз. школы-семинара по семиотике культуры. 8-18 сентября 1988, Архангельск. - Архангельск, 1988.- С. 76-78.

95. [Рец. на кн.:] В. Л. Янин, А. А. Зализняк. Новгородские грамоты на бересте (из раскопок 1977-1983 гг.). М., 1986 // Вопр. языкознания. — 1988. — № 4. C. $145-156$.

$$
1989^{49}
$$

${ }^{47}$ Corrigendum: Morris Halle ... [et al.], eds., Semiotics and the History of Culture: in Honor of Jurij Lotman: Studies in Russian [Advisory Committee: Cesare Segré, Thomas Winner, Viktor Živov] (UCLA Slavic studies, v. 17) (Columbus, Ohio: Slavica Publishers, 1988).

${ }^{48}$ Available online at: http://danefae.org/djvu/\#Zh

49 Addenda: (1) “Славянское историческое языкознание на съезде славистов” [Х съезд, София. 14-22 сент. 1988 г.],” Вестник МГУ. Сер. 9. Филология 3 (1989): 82-85; (2) Пустозерская проза: Протопоп Аввакум, Инок Епифаний, Поп Лазарь, Дьякон Федор [составление, предисловие, комментарий, переводы отдельных фрагментов М. Б. Плюхановой; научный редактор переводов В. М. Живов] (Голоса времен) (М.: Московский рабочий, 1989). 
96. Государственный миф в эпоху Просвещения и его разрушение в России конца XVIII века // Век Просвещения. Россия и Франция = Le siècle des lumières. Russie. France: Материалы науч. конф. «Випперовские чтения 1987». - Вып. 20. - М., 1989. - С. 141-165.

97. Значение орфографических правил в формировании русского извода церковнославянского языка // История русского литературного языка старшей поры: основные проблемы и перспективы исследования: Тез. докл. - М., 1989. - С. $38-40$.

98. Гедеон Криновский // Материалы к Богословско-церковному словарю. М., 1989. - С. 321. - (Богословские труды; Вып. 29). - Б. п.. ${ }^{50}$

99. Книжная справа в России // Материалы к Богословско-церковному словарю. - М., 1989. - С. 324-326. - (Богословские труды; Вып. 29). — Б. ח. ${ }^{51}$

10о. Поликарпов-Орлов Федор Поликарпович // Материалы к Богословскоцерковному словарю. - М., 1989. - С. 335 - (Богословские труды; Вып. 29). - Б. п. ${ }^{22}$

101. Стефан Яворский // Материалы к Богословско-церковному словарю. М., 1989. - С. 335-336. - (Богословские труды; Вып. 29). - Б. п. ${ }^{53}$

102. [Рец. на сб.:] Studia slavica mediaevalia et humanistica Riccardo Picchio dicata. Roma, 1986. Vol. 1—2 // Вопр. языкознания. —1989. — № 2. - С. 136141 .

$$
1990^{54}
$$

103. Культурные конфликты в истории русского литературного языка XVIII - начала XIX века. - М.: Ин-т рус. яз. АН СССР, 1990. — 272 с.

104. Проблемы формирования русского литературного языка нового типа в Петровскую и послепетровскую эпоху // Закономерности языковой эволюции: Тез. докл. - Рига, 1990. - С. 193-194.

$[615]$

105. «Простота» языка и ее реализации: о языке книги «Статир» (1683-1684 гг.) // Зборник Матице српске за филолоију и лингвистику, XXXIII (1990): Посвећено професору др Александру Младеновићу поводом 6о-годишњице живота. - Нови Сад, 1990. - С. 141-154.

\footnotetext{
${ }^{50}$ Available online at: http://www.btrudy.ru/resources/BT29/BT 29.pdf.

${ }^{51}$ Ibid.

${ }^{52}$ Ibid.

${ }^{53}$ Ibid.

${ }^{54}$ Addendum: Механизмы культуры, отв. ред. Б. А. Успенский; [составитель В. М. Живов] (М.: Наука, 1990). At head of title: Академия наук СССР. Научный совет по истории мировой культуры. Комиссия по изучению культуры как коммуникативной системы.
} 
106. Языковая ситуация Петровской эпохи и возникновение русского литературного языка нового типа // Festschrift L'ubomir Ďurovič zum 65. Geburtstag. - Wien, 1990. - C 451-469. - (Wiener Slavistisches Almanach; Bd. 25/26).

107. Существительное // Лингвистический энциклопедический словарь. M., 1990. - C. 499-500.55

108. Формообразование // Лингвистический энциклопедический словарь. - М., 1990. - C. $55^{8 .{ }^{56}}$

109. Части речи // Лингвистический энциклопедический словарь. - M., 1990. - C. $578 .{ }^{57}$

110. Устав св. Владимира // Материалы к Богословско-церковному словарю. - М., 1990. - С. 332-333. - (Богословские труды; Вып. 30). - Б. п. ${ }^{58}$

111. Устав кн. Ярослава // Материалы к Богословско-церковному словарю. - М., 1990. - С. 333-334. - (Богословские труды; Вып. 30). — Б. п. ${ }^{59}$

112. Уставная грамота кн. Ростислава // Материалы к Богословскоцерковному словарю. - М., 1990. - С. 333. - (Богословские труды; Вып. 30). - Б. п. ${ }^{60}$

113. Уставная грамота кн. Святослава // Материалы к Богословскоцерковному словарю. - М., 1990. - С. 333. - (Богословские труды; Вып. 30). - Б. п. ${ }^{61}$

\section{1}

114. Богословие иконы в первый период иконоборческих споров // XVIII Между-нар. конгресс византинистов: Резюме сообщ. - Т. 2. — М., 1991. — С. $1275-1276 .^{62}$

115. Космологические утопии как подтекст в «Стихах о неизвестном солдате» О. Мандельштама // Осип Мандельштам: К оо-летию со дня рождения: Поэтика и текстология: Материалы науч. конф. 27-29 декабря 1991 г. - M., 1991. - C. 74-78.

116. С Сихотворные переложения Псалтыри в истории русской литературы и духовности XVIII века // История и культура: Тезисы. - М., 1991.— С. 8486.

117. [Рец. на кн.:] Vasilij Kirillovič Trediakovskij Psalter 1753. Erstausgabe / Besorgt und kommentiert von A. Levitsky; Hrsg. von R. Olesch und H. Rothe.

${ }^{55}$ Available online at: http://www.tapemark.narod.ru/les/499f.html

${ }^{56}$ Available online at: http://www.tapemark.narod.ru/les/558d.html

${ }^{57}$ Available online at: http://www.tapemark.narod.ru/les/578b.html

${ }^{58}$ Available online at: http://www.btrudy.ru/resources/BT30/BT 30.pdf

${ }^{59}$ Ibid.

${ }^{60}$ Ibid.

${ }^{61} \mathrm{Ibid}$.

62 "Synopsis of a presentation" (резюме сообщения) delivered at the $18^{\text {th }}$ International Congress of Byzantinists. Zhivov, “Библиографическая справка,” 73о. For the full-text version, see VL 621 (no. 180). 
Paderborn; München; Wien; Zürich, 1989. LXXXIV + 663 S. (Biblia Slavica / Hrsg. von R. Olesch und H. Rothe unter Mitarbeit von F. Scholz. Serie III: Ostslavische Bibeln. Bd. 4: Russische Psalmenübersetzungen. b: Vasilij Kirillovič

[616] $555 .^{63}$

Trediakovskij) // Изв. АН СССР. Сер. лит. и яз. -1991. - Т. 50, № 6. - С. 551-

$$
1992^{64}
$$

118. Из истории русской грамматики: итеративы и имперфективы в структуре глагольной парадигмы // Доломоносовский период русского литературного языка = The Pre-Lomonosov Period of the Russian Literary Language: (Материалы конф. на Фагеруде, 20-25 мая 1989 г.). — Stockholm, 1992.- C. 247-270. - (Slavica Suecana; Vol. 1).

119. Космологические утопии в восприятии большевистской революции и антикосмологические мотивы в русской поэзии 1920-1930-х годов («Стихи о неизвестном солдате» О. Мандельштама) // Сб. ст. к 7о-летию проф.

Ю. М. Лотмана. - Тарту, 1992. - С. $411-434$. $^{65}$

120. Slavia Christiana и историко-культурный контекст Сказания о русской грамоте // Русская духовная культура / Под ред. Л. Магаротто и Д. Рицци. Тренто, 1992. - C. 71-125. - (Dipartimento di storia della civilta europea. Testi e ricerche; № 11$).{ }^{66}$

121. Особенности рецепции византийской культуры в Древней Руси // Проблемы синтеза культур: Тез. докл. - Севастополь, 1992. - C. 5-6. ${ }^{67}$

122. Как вращается «Красное колесо». - Новый мир. - 1992. — № 3. - С. $246-249$.

123. О сомнительном и недостоверном в историософии Н. А. Бердяева // Новый мир. —1992. - № 10. - С. 216-221.

124. Лингистические теории и языковая практика в истории русского литературного языка XVIII века: Автореф. дис. ... д-ра филол, наук. - M., 1992.

\section{3}

\footnotetext{
${ }^{63}$ Available online at: http://feb-web.ru/feb/izvest/1991/o6/916-5512.htm

${ }^{64}$ Addendum: Borys A. Uspienski, Wiktor M. Żywow, Car i Bóg: semiotyczne aspekty sakralizacji monarchy $w$ Rosji; przelozyl i wstepem opatrzyl Henryk Paprocki [Biblioteka mysli wspólczesnej] (Warszawa: Panstwowy Instytut Wydawniczy, 1992), a Polish-language translation of VL 613 (no. 85).

${ }^{65}$ Отв. ред. А. Мальц. Sее Издания кафедры русской литературы Тартуского университета (199220оo): Указатель содержания, URL: http://www.ruthenia.ru/document/381754.html.

${ }^{66}$ For the corrected and expanded version of this text, see $V L 621$ (no. 180). Zhivov, "Библиографическая справка," 730.

${ }^{67}$ Brief synopsis of a conference presentation eventually published in an expanded, full-text version in $V L$ 621 (no. 180). Zhivov, “Библиографическая справка,” 730.
} 
125. Богословие иконы в первый период иконоборческих споров // Православие и культура (Украинское православное братство святых Кирилла и Мефодия, Киев). -1993. - № 2. - С. $20-27 .{ }^{68}$

126. Гуманистическая традиция в развитии грамматического подхода к славянским литературным языкам в XVI-XVII вв. // Славянское языкознание: XI Междунар. съезд славистов. Братислава, сентябрь 1993 г.: Докл. рос. делегации. - М., 1993. - С. 106-121. ${ }^{69}$

127. Двоеверие и особый характер русской культурной истории // Philologia slavica: К 7о-летию акад. Н. И. Толстого. - М., 1993. - С. 50-59.

128. К К Крдыстории одного переложения псалма в русской литературе XVIII века // Jews and Slavs. - Vol. 1 / Ed. by W. Moskovich, S. Shvarzband and A. Alekseev. - Jerusalem; St. Petersburg, 1993. - C 132-16o.

$[617]$

129. Унификация склонения существительных в косвенных падежах мн. числа в памятниках XVII века: характер вариативности и обусловливающие ее факторы // Исследования по славянскому историческому языкознанию: Памяти проф. Г. А. Хабургаева. - М., 1993. - С. 93-110. ${ }^{70}$

130. О церковно-славянском языке // Рус. словесность. - 1993. - № 2. - С. $31-36$.

\section{$1994^{71}$}

131. Святость: Краткий словарь агиографических терминов. - М.: Гнозис, 1994. -112 c. $^{72}$

132. Византия и Древняя Русь: Диалог культур // Диалог культур: Материалы науч. конф. «Випперовские чтения - 1992». - Вып. XXV. - M., 1994. - C. 39-53.

133. Церковнославянская литературная традиция в русской литературе XVIII века и рецепция спора «древних» и «новых» // История культуры и поэтика. - М., 1994. - С. 62-82. (Ин-т славяноведения и балканистики $\mathrm{PAH})$.

${ }^{68}$ A "substantially-compressed variant" (существенно сокращенный вариант) of the full-text version eventually published in VL 621 (no. 180). Zhivov, “Библиографическая справка," 730.

${ }^{69}$ Available online at: http://danefae.org/djvu/\#Zh

${ }^{70}$ Available online at: http://danefae.org/djvu/\#Zh

${ }^{71}$ Addendum: “Царь и Бог: Семиотические аспекты сакрализации монарха в России” [в соавторстве с B.М. Живовым], in Б.А.Успенский, Избранные труды (Язык. Семиотика. Культура) (М.: Издательство «Гнозис», 1994), Т. 1. С. 110-218, reprint of VL 613 (nо. 85), available online in Библиотека Гумер: http://www.gumer.info/bibliotek Buks/Culture/Ysp/index.php.

${ }_{72}$ Published online by В.П.Коршунов аs В.М. Живов. Святость. Агиографические термины, URL: http://www.wco.ru/biblio/books/zhivovi/Main.htm 
134. Традиция и инновации в узусе письменного языка // Традиция и новые тенденции в развитии славянских литературных языков: Проблема динамики нормы: Тез. докл. междунар. науч. конф. Москва, 24-26 мая 1994 г. - M., 1994. -C. 10-12.

135. La doppia fede e il particolare carattere della storia della cultura russa // Intersezioni. Revista di storia delle idee. — Anno XIV, № 1, aprile 1994. — P. 95103.

136. Johann Ernst Glück. Grammatik der russischen Sprache (1704): Herausgegeben und mit einer Einleitung versehen. - Köln; Weimar; Wien: Böhlau Verlag, 1994. — 402 с - В соавт. с Г. Кайпертом и Б. А. Успенским.

\section{$1995^{73}$}

137. Буковница 1592 г. и ее место в истории русской грамматической мысли // The Language and Verse of Russia // In Honor of D. S. Worth / Ed. by

H. Birnbaum and M. Flier. - M., 1995. - C 291-303.

138. Особенности рецепции византийской культуры в древней Руси //

Ricerche slavistiche. - Vol. XLII (1995). - C. 3-48. - (Cultura letteraria medievale slava fra Bizanzio e Roma: prospettive di ricerca. Atti del Convegno di Castel Ivano, 24-25 settembre 1993). ${ }^{74}$

139. Светский и духовный литературный язык в России XVIII века: взаимодействие и взаимоотталкивание // Russica Romana. — Vol. II (1995). — C. $65-81$.

140. Usus scribendi: Простые претериты у летописца-самоучки // Russian Linguistics. - Vol. 19 (1995). - № 1. - C. 45-75.

$[618]$

141. Gedeon Krinovskii // Dictionary of Literary Biography. - Vol. 150. Early Modern Russian Writers, Late Seventeenth and Eighteenth Centuries / Ed. by M. C. Levitt. - Detroit; Washington, D. C.; London: Bruccoli Clark Layman, 1995. - P. 110-115.

142. Gavriil Petrov // Dictionary of Literary Biography. - Vol. 150. Early Modern Russian Writers, Late Seventeenth and Eighteenth Centuries / Ed. by M. C. Levitt. — Detroit; Washington, D. C.; London: Bruccoli Clark Layman, 1995. -P. 273278.

\footnotetext{
${ }^{73}$ Addendum: “Комментарии,” in Трубецкой Н.С. История. Культура. Язык; вступительные статьи Н. И. Толстого и Л.Н. Гумилева; составление, подготовка текста и комментарии В.М. Живова (Филологи мира) (М.: Издательская группа “Прогресс-Универс", 1995), 763-790.

${ }^{74}$ For the text of the slightly-revised and -expanded version, see VL 621 (no. 180).
} 
143. Il russo / A cura di N. Marcialis e A. Parenti. - Firenze : La Nuova Italia Editrice, 1995. - XXIV + 396 p. - (Biblioteca di cultura, 203; Lingue d'Europa, 4). - В соавт. с Л. Касаткиным и Л. Крысиным. ${ }^{75}$

144. [Рец. на изд.:] Vorläufiger Katalog Kirchenslavischer Homilien des beweglichen Jahreszyklus. Aus Handschriften des 11.—16. Jahrhunderts vorwiegend ostslavischer Provenienz / Zusammengestellt von Tat'jana V. Čertorickaja unter der Redaktion von H. Miklas. Opladen, 1994. (Abhandlungen der NordrheinWestfalischen Akademie der Wissenschaften; Bd. 91. Patristica Slavica / Hrsg. von H. Rothe; Bd. 1). X +795 S. // Изв. РАН. Сер. лит. и яз. — 1995. - Т. 54, № 3. C. $85-88$.

$$
1996^{76}
$$

145. Язык и культура в России XVIII века. - М.: Школа «Языки русской культуры», 1996. - 591 с. $^{77}$

146. Историческая морфология русского литературного языка XVIII века: узус, нормализация и норма // A Window on Russia: Papers from the V International Conference of the Study Group on Eighteenth-Century Russia. Gargnano 1994 / Ed. by M. Di Salvo and L. Hughes. — Roma: La Fenice Edizioni, 1996. - C. 285-292.

147. Культурные реформы в системе преобразований Петра I // Из истории русской культуры. - T. 3 (XVII - начало XVIII века). - М.: Языки рус. культуры, 1996. - С. $528-583 .{ }^{78}$

148. О церковно-славянском языке // А. Кравецкий, А. Плетнева. Церковнославянский язык. - М.: Просвещение, 1996. - С. $12-23 .{ }^{79}$

149. Палатальные сонорные у восточных славян: данные рукописей и историческая фонетика // Русистика. Славистика. Индоевропеистика: Сб. к бо-летию А. А. Зализняка. - М.: Индрик, 1996. - С. 178-202. ${ }^{80}$

\footnotetext{
${ }^{75}$ Corrigendum: chapters II, 1 ("Origini della lingua e tappe della sua evoluzione storica") and II, 2 ("Storia della norma letteraria") in L. Kasatkin, L. Krysin, V. Živov, Il russo, ed. by N. Marcialis and A. Parenti (Firenze: La Nuova Italia editrice, 1995), 15-81.

${ }^{76}$ Addenda: (1) "Государственный миф в эпоху Просвещения и его разрушение в России конца XVIII века," in Из истории русской культуры, (М.: Языки рус. культуры, 1996), Т 4. С. 657-683, a reprint of VL 614 (no. 96); (2) “Кощунственная поэзия в системе русской культуры конца XVIII-начала XIX века," in Из истории русской культуры, Т. 4 (1996), C. 701-753, a reprint of VL 610 (no. 56); (3) “Царь и Бог: семиотические аспекты сакрализации монарха в России" [в соавторстве с В.М. Живовым], in Успенский Б.А. Избранные труды. 2-е изд., испр. и перераб. (Язык. Семиотика. Культура). 3 vols. (M.: Языки русской культуры, 1996-7), Т. 1. С.205-337, a reprint of VL 613 (no. 85).

${ }^{77}$ Substantially-revised and -expanded version of VL 616 (no. 124). Sеe Иванов аnd Молдован, “Талант, ответственность и радость жизни.” The section on “Основные регистры книжного языка и процессы их формирования," С. 31-41, is available online at: http://danefae.org/djvu/\#Zh. For the English translation, see infra, Part II, no. 241.

${ }^{78}$ For the English translation, see Part II, infra, no. 302. For the later, expanded, Russian-language version, see $V L 621$ (no. 180).

79 Corrigendum: Плетнева А.А., Кравецкий, А.Г. Церковнославянский язык: Для общеобразоват. учеб. заведений гуманитар. профиля, свет. и духов. гимназий, лицеев, воскрес. шк. и самообразования [Науч. ред. В.М. Живов] (М.: Просвещение Учеб. лит., 1996).
} 
150. Религиозная реформа и индивидуальное начало в русской литературе XVII века // Из истории русской культуры. - Т. 3 (XVII - начало XVIII века). - М.: Языки рус. культуры, 1996. - С. $460-485 .{ }^{81}$

151. Скопцы в русской культуре: По поводу кн. $N$. Volkov. La secte russe des castrates. Traduit du russe par Z. Andreyev. Précédé de Communistes contre castrats

$[619]$

(1929-1930) par C. S. Ingerflom. Paris: Les Belles lettres, 1995. LXIII + 169 p. // Новое лит. обозрение. —1996. — № 18. - С. 396-40о.

152. Метаморфозы античного язычества в истории русской культуры XVII-XVIII вв. // Из истории русской культуры. - T. 4 (XVIII - начало XIX века). - М.: Языки рус. культуры, 1996. - С. 449-536. - В соавт. с Б. А. Успенским. ${ }^{82}$

153. О месте грамматики И. В. Пауса в развитии русской грамматической традиции: интерпретация отношений русского и церковнославянского // Вопр. языкознания. -1996. - № 6. - С. 3-30. - В соавт. с Г. Кайпертом.

154. Заметки об историческом синтаксисе русского языка (по поводу кн.: G. Hüttl-Folter. Syntaktische Studien zur neueren russischen Literatursprache. Die frühen Übersetzungen aus dem Französischen. Wien; Köln; Weimar: Böhlau Verlag, 1996. 319 S.) // Вопр. языкознания. —1997. — № 4. - С. 58-69.

155. П Памятники письменности древнерусского языка // Русский язык: Энциклопедия. — 2-е изд. - М.: Большая рос. энцикл., 1997. - С. 322-324. 156. Первые русские литературные биографии как социальное явление: Тредиаковский, Ломоносов, Сумароков // Новое лит. обозрение. - 1997. № $25 .-$ C. $24-83$.

157. Расставаясь со структурализмом (тезисы для дискуссии) // Вопр. языкознания. -1997. - № 3. - С. 3-14. - В соавт. с А. Тимберлейком. ${ }^{83}$ 158. Юродство - в Византии и других землях // Новое лит. обозрение. 1997. — № 24. - С. 390-396. - Рец. на кн.: С. А. Иванов. Византийское юродство. М.: Междунар. отношения, 1994. 235 с.

\footnotetext{
${ }^{80}$ Available online at: http://aurinko-25.narod.ru/zhivovi.pdf.

${ }^{81}$ Addendum: This is a slightly-expanded, Russian-language version of the English-language talk delivered in 1993, during the second workshop in Early East Slavic Culture, and published as "Religious Reform and the Emergence of the Individual in Russian Seventeenth-Century Literature," in Religion and Culture in Early Modern Russia and Ukraine, ed. Samuel H. Baron and Nancy Shields Kollmann (DeKalb: Northern Illinois University Press, 1997), 184-98. Zhivov, “Библиографическая справка," 731. Note that the bibliographic entry for the original, English-language version is missing from $V L$ under 1997.

${ }^{82}$ A slightly-revised version of VL 611 (no. 69). Zhivov, “Библиографическая справка,” 731.

${ }^{83}$ Available online at: http://danefae.org/djvu/\#Zh
} 


\section{$1998^{84}$}

159. Автономность письменного узуса и проблема преемственности в восточнославянской средневековой письменности // Славянское языкознание: XII Междунар. съезд славистов. Краков, 1998 г.: Докл. рос. делегации. - М.: Наука, 1998. - С. 212-247. ${ }^{85}$

16o. Об этническом и религиозном самосознании Нестора Летописца // Слово и культура: Памяти Никиты Ильича Толстого. - Т. 2. - М.: Индрик, 1998. - C. $321-337$.

161. Church Reforms in the Reign of Peter the Great // Russia in the Reign of Peter the Great: Old and New Perspectives: Proceedings of an International Workshop, held at the Villa Feltrinelli, Gargnano, Italy, 17-2o September 1997 / Ed. by A. Cross. - Pt. 1. - Cambridge, 1998. - P. 65-78. - (Study Group on Eighteenth-Century Russia Newsletter). ${ }^{86}$

[620]

$$
1999^{87}
$$

162. Въ пльну у ангеловъ, на дикомъ брегъ - ахъ! // Поэтика. История литературы. Лингвистика: Сб. к 7о-летию Вяч. Вс. Иванова. - М.: ОГИ, 1999. - С. $777-791$.

163. К истории форм 2 лица ед. числа презенса (о неоднородности элементов языка и ее исторических импликациях) // Славянские этюды: Сб. к юбилею С. М. Толстой. М: Индрик, 1999. - С. 181-202. ${ }^{88}$

164. Иван Сусанин и Петр Великий: О константах и переменных в составе исторических персонажей // Новое лит. обозрение. - 1999. - № 38(4). - C. $51-65 .{ }^{89}$

\footnotetext{
${ }^{84}$ Addendum: “Десять гуманитариев в поисках университета: Круглый стол о судьбе гуманитарного образования в России (Круглый стол по проблемам гуманитарного образования, состоявшийся 29. o6.1998 года)," Неприкосновенный запас 2 (1998), URL: http://magazines.russ.ru/nz/1998/2/krugstpr.html (partial-text version).

${ }^{85}$ Available online at: http://danefae.org/djvu/\#Zh

${ }^{86}$ Brief, English-language version of a talk delivered at the 1997 meeting of the Study Group on EighteenthCentury Russia. Zhivov, “Библиографическая справка," 731. For the full-length, Russian-language variant of the text, see $V L 621$ (no. 180).

${ }^{87}$ Addenda: (1) “«От рук слонов погибло двенадцать индусов»: Беседа с зам. директора Ин-та рус. яз. Рос. акад. наук В. Живовым и ст. науч. сотрудником ин-та Ю. Сафоновой,” записала И. Никитина, Культура (5 August 1999): 3; (2) [Book review]: С. А. Иванов. Византийское юродство (М.: Междунар. отношения, 1994), Византийский временник 58/83 (1999): 237-242, available at URL: http://vremennik.biz/opus/BB/58/53083; cf. VL 619 (no. 158).

${ }^{88}$ Available online at: http://narod.yandex.ru/disk/80456980o1/zhivov-2-prezens.pdf.html

${ }^{89}$ Available online at: http://magazines.russ.ru/nlo/1999/38/zhivov.html.
} 
165. Маргинальная культура в России и рождение интеллигенции // ПО $\Lambda$ YTPOПON: К 7о-летию Владимира Николаевича Топорова. - М.: Индрик, 1998. - С. $955-975 .{ }^{90}$

166. О превратностях истории или о незавершенности исторических парадигм // Россия = Russia. -1999. № 3. Культурные практики в идеологической перспективе: Россия, XVIII — начало XIX века. - С. 245260. ${ }^{91}$

167. Об оглядывании назад и частично по поводу сборника «Семидесятие как предмет истории русской культуры» (Москва - Венеция, 1998) // Неприкосновенный запас. — 1999. — № 2 (4). - С. $48-55 .{ }^{92}$

168. Первый литературный язык славян // Ricerche slavistiche. - XLVXLVI (1998-1999). - C. 99-136.

$\mathbf{2 0 0 0}^{93}$

169. Н. Н. Дурново и его идеи в области славянского исторического языкознания // Н. Н. Дурново. Избранные работы по истории русского языка. - М.: Языки рус. культуры, 200о. - C. VII-XXXVI.

${ }^{90}$ Corrigendum: The 1998 version of the article published in V. N. Toporov's festschrift was re-published under the same title in Новое литературное обозрение 3/37 (1999): 37-51; available online at: http://magazines.russ.ru/nlo/1999/37/givov.html. The compilers of the Zhivov bibliography in $V L$ appear to have conflated these two editions and mistakenly placed them under the entry for 1999.

${ }^{91}$ Re-published online by Александр Бокшицкий, Déjà vu. Энциклопедия культур (2002-2006), URL: http://ec-dejavu.ru/o/Official Nation-2.html. For a later, expanded version of this essay, see VL 621 (no. 180).

${ }^{92}$ Available online at: http://magazines.russ.ru/nz/1999/2/zhivov.html

93 Addenda: (1) “Особенности рецепции византийской культуры в древней Руси," in Из истории русской культуры, Т. 1 (Древняя Русь) (М.: Языки славянской культуры, 200о), 586-617, re-publication of $V L 617$ (no. 138); for the slightly-revised and -expanded version, see VL 621 (no. 180); (2) "Slavia Christiana и историко-культурный контекст Сказания о русской грамоте," in Из истории русской культуры, Т. 1 (2000), 552-585, re-publication of VL 616 (no. 120), with the text of the Skazanie (582-585). Zhivov, “Библиографическая справка," 730; (3) “Культурные реформы в системе преобразований Петра I," in Из истории русской культуры. T. 3. XVII - начало XVIII в. (М.: Языки рус. культуры, 200о), 528-583, republication of $V L 618$ (no. 147); (4) "Государственный миф в эпоху Просвещения и его разрушение в России конца XVIII века," in Из истории русской культуры, T. 6: XVIII-начало XIX века (М.: Языки русской культуры, 200o), 657-683, а reprint of VL 614 (no. 96); (5) В.М. Живов, Е.А. Земская, "Герта Хютль-Фольтер (1923-200о)," Вопросы языкознания 6 (2000):154-156; (6) “Какая защита нужна великому и могучему? Беседа с зам. директора Ин-та рус. яз. им. В.В. Виноградова Рос. акад. наук Виктором Живовым," записал Олег Мороз, Литературная газета (6 December 20oo), 1-2; (7) Panelist on "Россия как цивилизация" [streaming audio and transcript of Radio Free Europe/Radio Liberty program aired on 12 March 200о], ведущий Анатолий Стреляный; автор Елена Ольшанская, Радио Свобода, URL: http://archive.svoboda.org/programs/RYTT/200o/RYTT.031200.asp; (8) panelist on "Русские деньги" [transcript of a radio program aired on 19 November 2000 as part of RFE/RL series, "Россия как цивилизация"], ведущий Анатолий Стреляный; автор Елена Ольшанская, Paдио Свобода, URL: http://archive.svoboda.org/programs/RYTT/2000/RYTT.1119oo.asp; (9) panelist on "Русский язык" [transcript of a radio program aired on 10 December 2000 as part of RFE/RL series, "Россия как цивилизация”], ведущий Анатолий Стреляный; автор Елена Ольшанская, Рaдио Свобода, URL: http://archive.svoboda.org/programs/RYTT/2000/RYTT.12100o.asp. 
170. Воплощенная укоризна, или О благородном убожестве //

Неприкосновенный запас. — 2000. — №2 (10). - С. 46- 51.

171. Фоменко, утешитель обманутых вкладчиков // Итоги. - 200о. - №

35(221). - С. 40-41. - В соавт. с С. А. Ивановым.

172. Царапины на церах: Древнейший - из всех известных на сегодня -

книжный славянский текст найден в Новгороде этим летом // Итоги. - 2000.

- № 38 (224). - С. 62-66. - В соавт. с С. А. Ивановым.

173. [Рец. на кн.:] Handbuch der sprachwissenschaftlichen Russistik und ihrer Grenzdisziplinen / Hrsg. von Helmut Jachnow. Wiesbaden: Harrassowitz Verlag, 1999 // Вопр. языкознания. — 2000. — № 5. - С. 122-137. — В соавт. с Е. А. Земской и Л. П. Крысиным.

$[621]$ $\mathbf{2 0 0 1}^{94}$

174. [Вступит. ст. и ред.] Восемнадцатый век в работах Г. А. Гуковского, не загубленных советским хроносом // Г. А. Гуковский. Ранние работы по истории русской литературы XVIII века. - М.: Языки рус. культуры, 2001. C. 7 - 35 .

175. Заметки о византийской культуре в России раннего Нового времени: По поводу кн.: Olga B. Strakhov. The Byzantine Culture in Muscovite Rus': The Case of Evfimii Chudovskii (1620-1705). Köln; Weimar; Wien: Böhlau Verlag, 1998. (Bausteine zur slavische Philologie und Kulturgeschichte: Reihe A, Slavistische Forschungen; N. F. Bd. 26). 349 p. // Russia mediaevalis. - T. X, 1. München: Wilhelm Fink Verlag, 2001. - P. 325-344.

176. русского литературного языка нового типа // Слово в тексте и в словаре: Сб.

\footnotetext{
${ }^{94}$ Addenda: (1) “Исторический очерк о церковно-славянском языке,” in Плетнева А.А., Кравецкий А.Г., Церковнославянский язык. Учеб. для воскрес. (приходских) шк., правосл. гимназий и лицеев. Науч. ред. [и авт. вступ. ст.] В. М. Живов. 2-ое допол. и перер. изд. (М.: Изд-во “Древо добра ”, 20о1), 11-27, revised version of $V L 618$ (no. 148), available for free download on the website of the Московская православная духовная академия: http://www.mpda.ru/publ/text/61532.html; (2) panelist on "Русское бездорожье, Часть первая" [transcript of a radio program aired on 2 September 2001 as part of RFE/RL series, "Россия как цивилизация"], ведущий Анатолий Стреляный; автор Елена Ольшанская, Радио Сво6ода, URL: http://archive.svoboda.org/programs/RYTT/2001/RYTT.og0201.asp; (3) panelist on "Ревнители благочестия" [transcript of a radio program aired on 30 September 2001 as part of RFE/RL series, "Россия как цивилизация"], ведущий Анатолий Стреляный; автор Елена Ольшанская, Радио Свобода, URL: http://archive.svoboda.org/programs/RYTT/2001/RYTT.o93001.asp; (4) panelist on "Конец света" [transcript of a radio program aired on 14 October 2001 as part of RFE/RL series, "Россия как цивилизация"], ведущий Анатолий Стреляный; автор Елена Ольшанская, Paдио Свобода, URL: http://archive.svoboda.org/programs/RYTT/2001/RYTT.101401.asp; panelist on "Умное делание” [transcript of a radio program aired on 30 December 2001 as part of RFE/RL series, "Россия как цивилизация"], ведущий Анатолий Стреляный; автор Елена Ольшанская, Рaдио Свобода, URL: http://archive.svoboda.org/programs/RYTT/2001/RYTT.123001.asp.
} 
ст. к 7о-летию акад. Ю. Д. Апресяна. - М.: Языки рус. культуры, 2001. - С. $573-581 .^{95}$

177. Формирование норм русского литературного языка нового типа и их предыстория // Reflections on Russia in the Eighteenth Century / Ed. by J. Klein, S. Dixon and M. Fraanje. - Köln; Weimar; Wien: Böhlau Verlag, 2001. - C 377398.

178. Российское общество и его научные институции (диалогические замечания к статье Михаила Ямпольского) [“Личные заметки о научной институции,” Новое литературное обозрение 50 (2001): 96-114] // Новое лит. обозрение. - 2001. - № 52. - С. 106-114.

179. Ч Ч $\quad$ делать с Фуко, занимаясь русской историей? // Новое лит. обозрение. - 2001. -№ 49. - С. $85-87 \cdot{ }^{96}$

$\mathbf{2 0 0 2}^{97}$

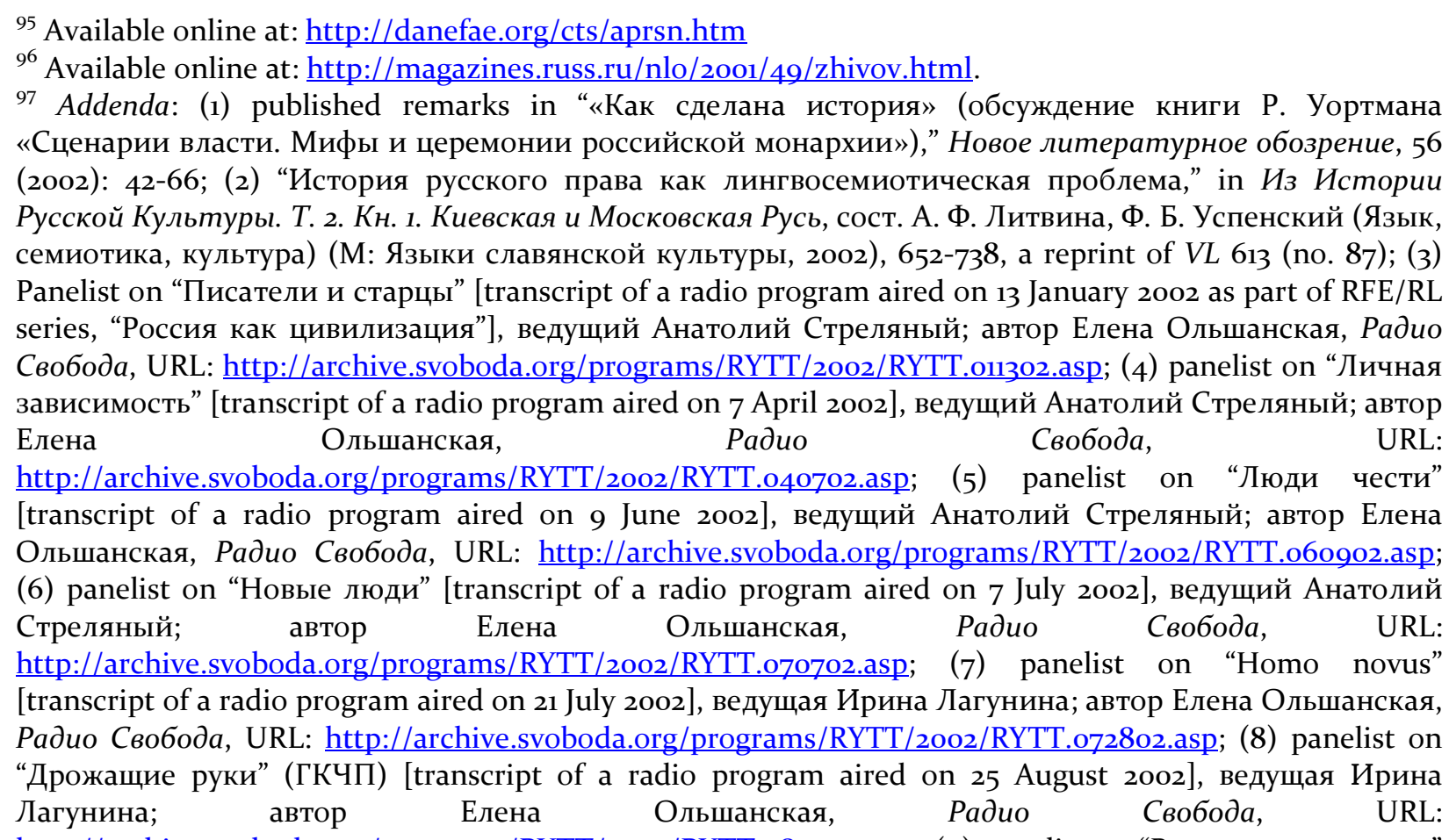
http://archive.svoboda.org/programs/RYTT/2002/RYTT.082502.asp ; (9) panelist on "Великое посольство" [transcript of a radio program aired on 8 September 2002], ведущая Ирина Лагунина; автор Елена Ольшанская, Радио Свобода, URL: http://archive.svoboda.org/programs/RYTT/2002/RYTT.ogo8oz.asp; (10) panelist on "Утро стрелецкой казни" [transcript of a radio program aired on 22 September 2002], ведущая Ирина Лагунина; автор Елена Ольшанская, Рaдио Свобода, URL: http://archive.svoboda.org/programs/RYTT/2002/RYTT.og2202.asp ; (11) panelist on “Человек барокко” [transcript of a radio program aired on 22 September 2002], ведущая Ирина Лагунина; автор Елена Ольшанская, Радио Свобода, URL: http://archive.svoboda.org/programs/RYTT/2002/RYTT.1006o2.asp; (12) panelist on "Взгляд со стороны" [transcript of a radio program aired on 3 November 2002], ведущая Ирина Лагунина; автор Елена Ольшанская, Рaдио Свобода, URL: http://archive.svoboda.org/programs/civil/2002/civil.110302.asp. 
180. Разыскания в области истории и предыстории русской культуры: Сб. ст. - М.: Языки слав. культуры, 2002. - 760 с. ${ }^{98}$

181. Литературный язык и язык литературы в России XVIII века // Russian Literature. - LII (2002). - P. 1-53. - (Special Issue. 18th Century Russian Literature).

182. Формы инфинитива в Житии протопопа Аввакума // Russica Romana. - IX (2002). In ricordo di M. Colucci - II. - C 277-293.

183. Науката като калфа на духа // Вестник литературен (София). - Год. 12 [2002].— № 6. - С. 14 .

184. Двуглавый орел в диалоге с литературой // Новый мир. - 2002. - № 2. - С. 174-183. - Рец. на кн.: А. Л. Зорин. Кормя двуглавого орла...: Литература и государственная идеология в России в последней трети XVIII - первой трети XIX века. - М.: Новое лит. обозрение, 2001. - 416 с. ${ }^{99}$

${ }^{98}$ Available online at: http://mexalib.com/view/39415 (last consulted 14 August 2014). This collection of eighteen essays includes: (1) an expanded variant of $V L 611$ (no. 6o); (2) a full-text version of $V L 615$ (no. 114) and $V L 616$ (no. 125); (3) a slightly-revised and -expanded version of $V L 616$ (no. 121) and VL 617 (no. 138): “Особенности рецепции византийской культуры в древней Руси," С. 73-115; available online at http://danefae.org/djvu/\#Zh; (4) a corrected and expanded version of VL 616 (no. 120); (5) reprints of VL 619 (no. 160); $V L 619$ (no. 152); $V L 614$ (no. 96); $V L 616$ (no. 128); VL 619 (no. 156); VL 610 (no. 56); $V L 620$ (no. 165); (6) a slightly-reworked and -expanded reprint of $V L 613$ (no. 87); (7) a revised version of $V L 616$ (no. 127): “Двоеверие и особый характер русской культурной истории,” С. 306-316; available online at http://danefae.org/djvu/\#Zh; (8) a slightly-revised variant of $V L 618$ (no. 150); (9) "Вопрос о церковной юрисдикции в российско-украинских отношениях XVII-XVIII веков,” а Russian-language, published version of a talk delivered at a 1994 conference in Cologne; for the text of the English-language version, see $V L 622$ (no. 187); (10) “Церковные преобразования в царствование Петра Великого," the full-length, Russian-language version of the English-language variant listed in VL 619 (no. 161); (11) an expanded version of $V L 618$ (no. 147), with additional annotations; and, finally, (12) an expanded edition of $V L 620$ (no. 166). Zhivov, “Библиографическая справка," 730-732.

${ }^{99}$ Available online at: http://magazines.russ.ru/novyi mi/2002/2/zhiv.html.

100 Addenda: (1) “Юродивые,” YоuTube (40:39) [Сергей Иванов and Виктор Живов discuss the phenomenon of юродство], Видео програмы «Закрытый показ», НТВ (26 February 2003), uploaded by Александр Гордон (29 July 2012), URL: http://www.youtube.com/watch?v=J 57rfjXNvk. A transcript of this program is available online: http://gordonoo3o.narod.ru/archive/10679/index.html; and as a chapter in Гордон А. Г. Ночные диалоги-2. (М.: Предлог, 2004); for Zhivov's assessment of Ivanov's work, see VL 619 (no. 158) and supra, Addendum 2, under the entry for 1999; (2) Panelist on "Работники 11-го часа" [transcript of a radio program aired on 6 April 2003 as part of RFE/RL series, "Россия как цивилизация”], ведущая Ирина Лагунина; автор Елена Ольшанская, Рaдио Свобода, URL: http://archive.svoboda.org/programs/civil/2003/civil.o40603.asp; (3) panelist on "Сердце на кончике пальца" [transcript of a radio program aired on 18 Мау 2003], ведущая Ирина Лагунина; автор Елена Ольшанская, Радио Свобода, URL: http://archive.svoboda.org/programs/civil/2003/civil.051803.asp; (4) panelist on "Боярская республика" [transcript of a radio program aired on 24 August 2003], ведущая Ирина Лагунина; автор Елена Ольшанская, Рaдио Свобода, URL: http://archive.svoboda.org/programs/civil/2003/civil.o82403.asp ; (5) panelist on “Дневник монаха" 
185. Деловой язык средневековой Руси и синтаксис берестяных грамот // Берестяные грамоты: 50 лет открытия и изучения: Материалы междунар. конф. Великий Новгород, 24-27 сентября 2001 г. / Под ред. В. Л. Янина. М.: Индрик, 2003. - С. 284-295.

186. ХОУ-ть-И: Об идеосинкратических факторах при выборе морфологических вариантов // Rusistika • Slavistika • Lingvistika: Festschrift fur Werner Lehfeldt zum 6o. Geburtstag / Hrsg. von Sebastian Kempgen, Ulrich Schweier und Tilman Berger. - München: Otto Sagner, 2003. - C. 320-329. (Die Welt der Slaven; Sammelbände. Bd. 19).

187. The Problem of Church Jurisdiction in Russian-Ukrainian Relations (Seventeenth and Early Eighteenth Centuries // Culture, Nation, and Identity: the Ukrainian-Russian Encounter (160o-1945) / Ed. by A. Kappeler, Z. E. Kohut, F. E. Sysyn, M. von Hagen. - Edmonton; Toronto: Canadian Institute of Ukrainian Studies Press, 2003. - P. 1-18. ${ }^{101}$

$$
2004^{102}
$$

188. Из церковной истории времен Петра Великого: Исследования и материалы. - М.: Новое лит. обозрение, 2004. - 360 с.

189. Очерки исторической морфологии русского языка XVII-XVIII веков. - М.: Языки слав. культуры, 2004. - 655 с. ${ }^{103}$

19o. Время и его собственник в России на пути от царства к империи // Человек между Царством и Империей: Сб. материалов междунар. конф. / Под ред. М. С. Киселевой. - М.: Ин-т человека РАН, 2003. - С. 18-26.

[transcript of a radio program aired on 7 September 2003], ведущая Ирина Лагунина; автор Елена Ольшанская, Радио Свобода, URL: http://archive.svoboda.org/programs/civil/2003/civil.ogo703.asp; (6) panelist on "Первопечатник" [transcript of a radio program aired on 28 November 2003], автор и ведущая Елена Ольшанская; редактор Андрей Бабицкий, Радио Свобода, URL: http://archive.svoboda.org/programs/civil/2003/civil.112803.asp.

${ }^{101}$ Corrigendum: The correct title is "The Question of Ecclesiastical Jurisdiction in Russian-Ukrainian Relations (Seventeenth and Early Eighteenth Centuries).” The English-language, published version of a talk delivered in Cologne at a 1994 conference sponsored by the Seminar for East European History at Cologne University, the Harriman Institute at Columbia University, and the Canadian Institute of Ukrainian Studies at the University of Alberta. For the Russian-language version, see VL 621 (no. 180). Zhivov, "Библиографическая справка," 731.

${ }^{102}$ Addenda: (1) Panelist on "Обратная перспектива" [transcript of a radio program aired on 5 June 2004 as part of RFE/RL series, "Россия как цивилизация”], автор и ведущая Елена Ольшанская; редактор Ирина Лагунина, URL: http://archive.svoboda.org/programs/civil/2004/civil.o60504.asp; (2) panelist on "Преображенная реальность ("Обратная перспектива" - 2)" [transcript of a radio program aired on 19 June 2004], автор и ведущая Елена Ольшанская; редактор Ирина Лагунина, URL: http://archive.svoboda.org/programs/civil/2004/civil.o61904.asp.

${ }^{103}$ Очерки исторической морфологии русского языка XVII-XVIII вв. [фрагмент], С. 44-77, is available online at: http://danefae.org/djvu/\#Zh 
191. Заметки о времени и досуге // Сокровенные смыслы: Слово. Текст. Культура: Сб. ст. в честь Н. Д. Арутюновой / Под ред. Ю. Д. Апресяна. - М.: Языки слав, культуры, 2004. - С. 744-754.

192. Об исторической науке у Карла Гинзбурга // Новое лит. обозрение. 2004. — № 65. - С. 6-10. ${ }^{104}$

193. Улики подлинности и улики поддельности: По поводу кн. Edward L. Keenan. Josef Dobrovsky and the Origins of the Igor' Tale. Cambridge, Mass.: Distributed by Harvard Univ. Press, 2003. хxiіi + 541 р. // Рус. яз. в науч. освещении. - 2004. - № 8. - С. 238-265.

194. Формирование языкового стандарта в России: особенности начального этапа // Резюмета на докладите от международната конференция «Стандарт и субстандарт - диахронии и синхронии аспекта». Варна - Шумен, 1519.09.2004. - Шумен: Унив. изд-во «Епископ Константин Преславски», 2004. - C. $13-14$.

[623]

195. Два пространства русского средневековья и их позднейшие метаморфозы // Отечественные записки. — 2004. - № 5(20). - С. 8-27. ${ }^{105}$ 196. "Комментарий: блеск и нищета жанра в современную эпоху (Стенограмма «круглого стола» в рамках XI Лотмановских чтений. Москва, РГГУ, 20 декабря 2003 г.)," Новое литературное обозрение 66 (2004), 103-120. ${ }^{106}$ 197. Чего не может фальсификатор // Отечественные записки. -2004. № 4(19). - С. 345-349. - Рец. на кн.: А. А. Зализняк. «Слово о полку Игореве»: взгляд лингвиста. М.: Языки слав. культуры, 2004. 352 с. $^{107}$

198. [Рец. на кн.:] Compendium Grammaticae Russicae (1731). Die erste Akademiegrammatik der russischen Sprache / Hrsg. von Helmut Keipert in Verbindung mit Andrea Huterer. München: Verlag der Bayerischen Akademie der Wissenschaften in Kommission: Verlag C. H. Beck, 2002. - 219 S. (Bayerische Akademie der Wissenschaften. Philosophisch-historische Klasse. Abhandlungen; N. F. Hft. 121) // Вопр. языкознания. —2004. — № 1. - C. 145-151.

$$
2005^{108}
$$

\footnotetext{
${ }^{104}$ Available online at: http://magazines.russ.ru/nlo/2004/65/zhı.html.

${ }^{105}$ Available online at: (1) http://www.strana-oz.ru/2004/5/dva-prostranstva-russkogo-srednevekovya-i-ihpozdneyshie-metamorfozy.

${ }^{106}$ Available online at: http://magazines.russ.ru/nlo/2004/66/kommı.html.

${ }^{107}$ Available online at: (1) http://www.strana-oz.ru/2004/4/chego-ne-mozhet-falsifikator.

${ }_{108}$ Addenda: (1) "A Phenomenological Apologia for Herzen (Herzen's Philosophical World Outlook by G. Shpet)," translated by Aram Yavrumyan, Social Sciences, 36: 4 (2005): 99-107, a translation of VL 623 (no. 199); (2) [Book review]: The Petrine Revolution in Russian Culture by James Cracraft, The Slavic and East European Journal 49:2 (Summer 2005): 337-338; (3) “Исторический очерк о церковнославянском языке,” in Плетнева А.А., Кравецкий А.Г. Церковнославянский язык. Уч. изд. для общеобр.уч.зав., дух.училищ, гимназий, воск.школ и самообраз. 3-е, перер. и доп. изд. (М.: Изд.совет РПЦ, 2005), 9-20,
} 
199. Апология Герцена в феноменологическом исполнении («Философское мировоззрение Герцена» Г. Г. Шпета) // Новое лит. обозрение. 2005. — № 71. - C. $166-174 .^{109}$

2oo. $\quad$ Ранняя восточнославянская агиография и проблема жанра в древнерусской литературе // Язык. Личность. Текст: Сб. ст. к 7о-летию Т. М. Николаевой / Под ред. В. Н. Топорова. - М.: Языки слав. культур, 2005. - С. $720-734$.

201. Наука выживания и выживание науки // Новое лит. обозрение. 2005. № $74 .-$ C. $25-33$. $^{110}$

202. Язык и революция: Размышления над старой книгой А. М. Селищева «Язык революционной эпохи» и над процессами, которые Селищев не успел описать // Отечественные записки. — 2005. — № 2. - С. 175-200. ${ }^{111}$

revised version of $V L 618$ (no. 148); (4) “Новая эра. Виктор Живов: История византийской культуры. Передача первая" [transcript of a radio program aired on 14 January 2005 as part of RFE/RL series, "Россия как цивилизация”], автор и ведущая Елена Ольшанская; редактор Алексей Цветков, URL: http://archive.svoboda.org/programs/civil/2005/civil.o11405.asp; (5) “Новая эра. Виктор Живов: История византийской культуры. Передача вторая" [transcript of a radio program aired on 28 February 2005], автор и ведущая Елена Ольшанская; редактор Алексей Цветков, URL: http://archive.svoboda.org/programs/civil/2005/civil.021105.asp; (6) “Новая эра (Из истории византийской культуры)" [transcript of a radio program aired on 21 March 2005], автор и ведущая Елена Ольшанская; редактор Алексей Цветков, URL: http://archive.svoboda.org/programs/civil/2005/civil.032105.asp; (7) "Новая эра (4). Виктор Живов: Из истории византийской культуры" [transcript of a radio program aired on (12 April 2005)], автор и ведущая Елена Ольшанская; редактор Алексей Цветков, URL: http://archive.svoboda.org/programs/civil/2005/civil.041205.asp; (8) "Виктор Живов: Из истории византийской культуры (Новая эра. Передача пятая)" [transcript of a radio program aired on (16 May 2005)], автор и ведущая Елена Ольшанская; редактор Алексей Цветков, URL: http://archive.svoboda.org/programs/civil/2005/civil.051605.asp; (9) "Виктор Живов: Из истории византийской культуры (Новая эра. Передача шестая)" [transcript of a radio program aired on (13 June 2005?)], автор и ведущая Елена Ольшанская; редактор Алексей Цветков, URL: http://archive.svoboda.org/programs/civil/2005/civil.o61305.asp; (10) "Виктор Живов: Из истории византийской культуры (Новая эра. Передача седьмая)" [transcript of a radio program aired on (11 July 2005?)], автор и ведущая Елена Ольшанская; редактор Алексей Цветков, URL: http://archive.svoboda.org/programs/civil/2005/civil.o71105.asp; (11) “Новая эра. Виктор Живов: Из истории византийской культуры. Передача восьмая" [transcript of a radio program aired on 16 September 2005], автор и ведущая Елена Ольшанская; редактор Алексей Цветков, URL: http://archive.svoboda.org/programs/civil/2005/civil.og1605.asp; (12) “Новая эра. Виктор Живов: Из истории византийской культуры. Передача девятая" [transcript of a radio program aired on 3 October 2005], автор и ведущая Елена Ольшанская; редактор Алексей Цветков, URL: http://archive.svoboda.org/programs/civil/2005/civil.101705.asp; (13) “Новая эра. Виктор Живов: Из истории византийской культуры. Передача десятая” [transcript of a radio program aired on 14 November 2005], автор и ведущая Елена Ольшанская; редактор Алексей Цветков, URL: http://archive.svoboda.org/programs/civil/2005/civil.111405.asp.

${ }^{109}$ Available online at: (1) http://magazines.russ.ru/nlo/2005/71/zhi8.html.

${ }^{110}$ Available online at: $\underline{\text { http://magazines.russ.ru/nlo/2005/74/zhiz.html. }}$

${ }^{111}$ Available online at: (1) http://www.strana-oz.ru/2005/2/yazyk-i-revolyuciya-razmyshleniya-nad-staroyknigoy-a-m-selishcheva. 
203. $\quad$ К проблематике и специфике русского классицизма: Оды Василия Майкова // И. Клейн. Пути культурного импорта: Труды по русской литературе XVIII века. - М.: Языки слав. культуры, 2005. - С. 393-445. - В соавт. с И. Клейном.

204. О лингвистических трудах А. А. Зализняка: (К семидесятилетию со дня рождения) // Изв. РАН. Сер. лит. и яз. - 2005. - Т. 64, № 3. - С. 3-12. - В соавт. с В. А. Плунгяном.

$2006^{112}$

205. Восточнославянское правописание XI-XIII века. М.: Языки славянской культуры, 2006. ${ }^{113}$

206. Совершенный словоиспытатель: Памяти Михаила Леоновича

Гаспарова // Новое лит. обозрение. — 2006. — № 77. - С. $28-35 .{ }^{114}$

\section{Part II: A Bibliography of the Works of V. M. Zhivov (2006-2013)}

The following section of the bibliography contains 148 entries for the eight years in question. ${ }^{115}$ For ease of reference, each of the entries is numbered (starting at no. 207) and organized chronologically by year of publication. Nearly every annual entry includes books, scholarly articles, book reviews, and online publications, in that order of presentation. Taken together, the entries in Part II are intended to serve as a supplement to, and a direct continuation of, the entries from $V L$ (reproduced above). When consulted

112 Addendum: “Современное значение празднования Дня славянской письменности и культуры в России" [transcript of interview conducted by RFE/RL correspondent Марьяна Торочешникова], "Время Свободы” (24 Мау 2006), ведущий программы Виктор Нехезин, Рaдио Свободы, URL: http://www.svoboda.org/content/transcript/158706.html.

113 This collection of essays includes "Норма, вариативность и орфографические правила в восточнославянском правописании XI-XIII вв.," Восточнославянское правописание XI-XIII века, 975; available online at: https://app.box.com/shared/ozko4yagsg; as well as reprints of VL 611 (no. 66); VL 612 (no. 74); VL 618 (no. 149); VL 620 (no. 162); VL 622 (no. 186), VL 613 (no. 83), and VL 620 (no. 169).

${ }^{114}$ Available online at: http://magazines.russ.ru/nlo/2006/77/zh5.html.

${ }^{115}$ This updated list of publications was compiled on the basis of both published and unpublished sources, including: (1) "В.М.Живов. Список работ, опубликованных в 2007-2012 гг.," an unpublished MSS kindly shared with the compiler of the present bibliography by Iu. V. Kagarlitskii; (2) "Selected Publications," formerly listed on the website of the Department of Slavic Languages and Literatures, University of California-Berkeley (now available as a snapshot from 9 March 2013 via the Internet Archive's "Wayback Machine": https://web.archive.org/web/20130309182414/http://slavic.berkeley.edu/faculty.html); (3) Zhivov, "Библиографическая справка"; (4) Sichinava, "В. М. Живов: Избранная библиография"; (5) freelyavailable online resources, such as Danefae.org; Svodnyi katalog bibliotek Rossii v svobodnom dostupenavigator bibliotechnykh resursov (Natsional'nyi informatsionno-bibliotechnyi tsentr "LIBNET", 2010-2012), URL: http://skbr2.nilc.ru/; Elibrary.ru (ООО Научная электронная библиотека, 2000-2014), URL: http://elibrary.ru/author items.asp?authorid=104350; and Zhurnal'nyi zal (1996-2013), URL: http://magazines.russ.ru:81/authors/z/zhivov/; as well as (6) the standard complement of subscriptionbased bibliographic tools, such as OCLC/WorldCat, Karlsruher Virtueller Katalog, JSTOR, American Bibliography of Slavic and East European Studies Online, Russian Academy Bibliographies Online, and Russian National Bibliography Online. 
together, both parts of this bibliography provide the most up-to-date list, and serve as the basis for a more complete inventory of, the works of V. M. Zhivov.

\section{6}

207. "Стратегии пророчества: Проповедь Стефана Яворского на память Алексея Человека Божия," in Cтux, язык, поэзия. Памяти Михаила Леоновича Гаспарова [Редколлегия, Х. Баран ... et al.] (Москва: РГГУ, 2006), 201-210.

208. "Из истории слов: грњховодник," in “Iter philologicum: Festschrift für Helmut Keipert zum 65. Geburtstag," special issue, Die Welt der Slaven, Sammelbände. Bd. 28, herausgegeben von Daniel Bunčić und Nikolaos Trunte (München: Sagner, 2006), 165-180.

209. "Post scriptum к поэтике бытового поведения и к посвященному ей «круглому столу»," Новое литературное обозрение 82 (2006): 122-128. Available online at: http://magazines.russ.ru/nlo/2006/82/zh6.html

210. "На возвратном пути к имперской благопристойности. Заметки о Федеральном законе Российской Федерации от 1 июня 2005 г. N 53-ФЗ О государственном языке Российской Федерации," Russian Language Journal 56 (2006): 57-66. Available online at: http://danefae.org/djvu/\#Zh

211. [Review]: Ферм Л. Вариативное беспредложное глагольное управление в русском языке XVIII века [Södertörn academic studies, 26] (Huddinge: Södertörns högskola, 2005), Вопросы языкознания 5 (2006): 139-146.

2007

212. “Всякая всячина и создание екатерининского политического дискурса," in Roger Bartlett and Gabriela Lehmann-Carli, eds., Eighteenth-century Russia: Society, Culture, Economy: Papers from the VII International Conference of the Study Group on Eighteenth-Century Russia, Wittenberg 2004 (Geschichte, Forschung und Wissenschaft, [Bd. 23]) (Berlin: Lit; London: Global [distributor], 2007), 251-265.

213. “Лингвистические обстоятельства умерщвления новорожденных," in Язык как материя смысла: сборник статей к 9о-летию академика Н. Ю.

Шведовой [редкол.: М. В. Ляпон (отв. ред.) и др.] (Москва: Азбуковник, 2007), $548-563$.

214. “История русского литературного языка. Введение,” in Русский язык и его история: Программы кафедры Русского языка для студентов филологических факультетов государственных университетов. Специальность 2001: русский язык и литература. Изд. 2-е, испр. и доп., под общей редакцией М. Л. Ремнёвой (М.: МАКС Пресс, 2007), 221-243. Available online at: http://www.philol.msu.ru/data/programs/russian.pdf

215. "К типологии барокко в русской литературе XVII-начала XVIII в.," in Человек в культуре русского барокко: сборник статей по материалам международной конференции. ИФ РАН Москва, Историко-архитектурный 
музей “Новый Иерусалим ”. 28-зо сентября 2006 г., отв. ред. М. С. Киселева (М: Ин-т Философии РАН, 2007), 11-31.

216. "Неизвестное сочинение митрополита Стефана Яворского с протестом против учреждения Синода,” in Петр Великий, составление и редактор Е.В. Анисимов (Нация и культура. Новые исследования. История. Россия/Russia) (М.: ОГИ, 2007), 241-333. ${ }^{116}$

217. “Дательный самостоятельный в Повести временных лет и Житии Феодосия: проблемы референтной структуры и порядка слов,” in A.И. Соболевский и русское историческое языкознание (к 15о-летию со дня рождения ученого). Тезисы докладов Международной научной конференции (Москва, 8-11 июня 2007 г.) [Редакционная коллегия сборника: В. Б. Крысько, К. А. Максимович, А. М. Молдован] (М.: Ин-т русского языка РАН, 2007), 21. Available online at: http://www.ruslang.ru/doc/sobolevskijo7 tez.pdf

218. “Язык и стиль А.П. Сумарокова,” Русский язык в научном освещении 1/13 (2007): 7-51. Available online at: http://www.ruslang.ru/doc/rjano13.pdf

219. [Review]: Tuпографский Устав: Устав с кондакарем конца ХІ - начала ХІІ века. Под ред. Б.А. Успенского. Т. 1-3 (М.: Языки славянских культур, 2006), Русский язык в научном освещении, 1/13 (2007): 318-319. Available online at: http://www.ruslang.ru/doc/rjano13.pdf

220. [Review]: Helmut Keipert. Das «Sprache»-Kapitel in August Ludwig

Schlözers «Nestorъ» und die Grundlegung der historisch-vergleichended Methode für die slavische Sprachwissenschaft. Mit einem Anhang: Josef Dobrovskýs «Slavin»Artikel «Über die altslawonische Sprache nach Schlözer» und dessen russische Übersetzung von Aleksandr Chr. Vostokov / Hrsg. von H. Keipert in Verbindung mit Michail Šmil'evič Fajnštejn. Göttingen: Vanderhoeck \& Ruprecht, 2006. 137 S. (Anhandlungen der Akademie der Wissenschaften zu Göttingen, Philologischhistorische Klasse, Dritte Folge. Bd. 276), Русский язык в научном освещении, 1/13 (2007): 320-321. Available online at: http://www.ruslang.ru/doc/rjano13.pdf

221. [Review]: А. И. Соболевский. Труды по истории русского языка. Т. 2: Статьи и рецензии. Сост., подгот. текста, предисл., коммент. и указ. В. Б. Крысько (М.: Языки славянских культур, 2006). 688 с. (Классики отечественной филологии), Русский язык в научном освещении, 1/13 (2007): 321-322. Available online at: http://www.ruslang.ru/doc/rjano13.pdf

222. [Review]: A. П. Майоров, Очерки лексики региональной деловой письменности XVIII века (М.: Азбуковник, 2006), Русский язык в научном

\footnotetext{
${ }^{116}$ An earlier version of this article, entitled "Неизвестное сочинение митрополита Стефана Яворского как памятник церковной мысли эпохи петровских преобразований,” was presented at the Second International Study Church Conference on Theology and Spirituality of the Russian Orthodox (Вторая Международная научная церковная конференция, посвященная 10оо-летию Крещения Руси “Богословие и духовность Русской Православной Церкви”. Москва, 11-19 мая 1987 года). However, it did not appear in the published proceedings of this conference: Тысячелетие крещения Руси [под общей редакцией митрополита киевского и галицкого Филарета], 2 vols. (М.: Изд. Московской патриархии, 1988-1989). Although this conference presentation was still listed as a "pre-print" in VL 621 (no. 180), it was not included in the 2006 "Список научных трудов Виктора Марковича Живова."
} 
освещении, 1/13 (2007): 322-323. Available online at:

http://www.ruslang.ru/doc/rjano13.pdf

223. [Review]: В. М. Загребин, Исследования памятников южнославянской и древнерусской письменности (М.; СПб.: Альянс-Архео, 2006), Русский язык в научном освещении, 1/13 (2007):324-325. Available online at:

http://www.ruslang.ru/doc/rjano13.pdf

224. "Русская ода: история жанра. [Review: Алексеева Н.Ю. Русская ода:

Развитие одической формы в XVII-XVIII веках (СПб.: Наука, 2005). -369 с. - 8 оо экз.]," Новое литературное обозрение 87 (2007): 406-413 (co-authored with Joachim Klein). Available online at:

http://magazines.russ.ru/nlo/2007/87/kl 43.html

225. [Review]: М.В. Корогодина. Исповедь в России в XIV - XIX веках.

Исследование и тексты (СПб.: Дмитрий Буланин, 2006), Славяноведение 2 (2007): 95-102.

226. [Review]: Frithjof Benjamin Schenk, Aleksandr Nevskij: Heiliger-FürstNationalheld. Ein Erinnerungsfigur im russischen kulturellen Gedächtnis (1263200o) (Köln: Böhlau, 2004), Kritika: Explorations in Russian and Eurasian History 8:3 (Summer 2007): 661-671.

227. Наталия Демина, "Российские грехи" [synopsis of "Грех в России: с древности до наших дней," a public lecture delivered by V. M. Zhivov in Moscow at the second International Book Festival (II Международный московский открытый книжный фестиваль) on 11 June 2007], Полит.py (1 August 2007), URL: http://www.polit.ru/article/2007/o8/o1/zhivov/.

228. “Святость и грех в русской литературе" (38:59) [streaming video of TV talk-show panel], "Тем временем" с Александром Архангельским (2007), Россия-Культура, uploaded 9 August 2013, URL:

https://video.yandex.ru/users/snows93x/view/1502/?cauthor=snows93x\&cid=21.

2008

229. “Чувствительный национализм: Карамзин, Ростопчин, национальный суверенитет и поиски национальной идентичности," Новое литературное обозрение 91 (2008): 114-140. Available online at: (1)

http://magazines.russ.ru/nlo/2008/91/zh7.html

230. "Language as Tradition," in Robert Adam and Matthew Hardy, eds., Tradition Today: Continuity in Architecture and Society [proceedings of 2002 conference sponsored by the International Network for Traditional Buildings, Architecture and Urbanism] (Southampton: WIT, 2008), 54-70.

231. “жА/ж: чтение, произношение и правописание в XI-XIII веке," in Miscellanea Slavica: сборник статей к 7о-летию Бориса Андреевича Успенского [сост. Ф.Б. Успенский] (Труды по филологии и истории) (Москва: Индрик, 2008): 239-255.

232. "Референтная структура и порядок слов: дательный самостоятельный в двух древних церковнославянских текстах,” Русский язык в научном 
освещении 1 (2008): 5-56. Available online at: http://www.ruslang.ru/doc/rjano15.pdf

233. "Референтная структура и порядок слов: Дательный самостоятельный в двух древних церковнославянских текстах,” ХIV Муѓународен конгрес на слависти. Охрид, 10-16 септемеври 20о8. 36орник на резимеа. Т.I. Лингвистика. Уредник С. Велковска (Скопје: Македонски славистички комитет, 2008), 151.

234. "Император Траян, девица Фальконилла и провонявший монах: их приключения в России XVIII века," Факты и знаки: Исследования по семиотике истории 1 (2008): 245-268.

235. "Покаянная дисциплина и индивидуальное благочестие в истории русского православия," in Дружба: ее формы, испытания и дары: Успенские чтения [составитель Константин Сигов] (Киев : Дух і літера, 2008), 303-343. Available online at: http://ru.duh-i-litera.com/pokayannaya-distsiplina-iindividualnoe-blagochestie-v-istorii-russkogo-pravoslaviya/

236. “Юридические кодексы и режим интерпретации," in Динамические модели: Слово. Предложение. Текст: Сборник статей в честь Е.В. Падучевой [редколлегия: А. В. Бондаренко, Г. И. Кустова, Р. И Розена] (Studia philologica) (М.: Языки славянских культур, 2008), 309-328.

237. "Православная периферия между раем и адом - что там бывает?," in Международная конференция «Маргиналии 20о8: периферия культуры и границы текста». Юрьев-Польский, 3-5 октября 2008 г. Тезисы докладов (М.: [НИВЦ МГУ], 2008), 56-57.

238. "Понятие греха стало коллективным: беседа с зам. директора Ин-та рус. яз. им. В.В. Виноградова Рос. акад. наук Виктором Марковичем Живовым," записал С. Шаповал. Культура (2 October 2008): 4.

239. "Михаил Задорнов" (52.53) [Streaming video of Zhivov's strenuous objections (21:46) against Zadornov's views on Russian etymology from a TV talkshow], «Гордон Кихот», ведущий программы Александр Гордон (19 September 2008), Первый канал, uploaded by Svetoch Su (10 January 2012), URL:

http://www.youtube.com/watch?v=oQMBRgTgczk.

240. "Революция, данная нам в ощущениях" (53.0о) [podcast and transcript of RFE/RL panel about the topic of the latest Банные чтения], “Свобода в клубах," ведущая программы Елена Фанайлова, published 30 March 2008, Рaдио Свобода, URL: http://www.svoboda.org/content/transcript/441506.html.

\section{9}

241. Language and Culture in Eighteenth-Century Russia, by Victor Zhivov; trans. Marcus C. Levitt (Studies in Russian and Slavic literatures, cultures and history) (Boston: Academic Studies Press, 2009). ${ }^{117}$

${ }^{117}$ English translation of $V L 618$ (no. 145), with a new preface by the author. The production of the Englishlanguage text was supported by the Mikhail Prokhorov Foundation (translation program Transcript) and 
242. Очерки исторической семантики русского языка раннего Нового времени, под редакцией В. М. Живова (Studia philologica) (М: Языки славянских культур, 2009).

243. “История понятий, история культуры, история общества," in ibid., 5-26.

244. "Время и его собственник в России раннего Нового времени (XVI-XVIII века)," in ibid., 27-101.

245. “Заспанные младенцы и матери-детоубийцы: из истории слов и понятий," in ibid., 370-404.

246. “Грьховодник. К истории слова и понятия," in ibid., 405-430.

247. "The Igor' Tale from the Perspective of Cultural History," in Harvey Goldblatt and Nancy Shields Kollmann, eds., "Rus' Writ Large: Language, Histories, Cultures: Essays Presented in Honor of Michael S. Flier on his SixtyFifth Birthday," special issue, Harvard Ukrainian Studies 28: 1-4 (2006) [Cambridge, MA: Ukrainian Research Institute of Harvard University, 2009]: 353-362

248. "Дисциплинарная революция и борьба с суеверием в России XVIII века: «провалы» и их последствия," in Антропология революции: сборник статей по материалам XVI Банных чтений журнала «Новое литературное обозрение» (Москва, 27-29 марта 2008 года) [сост. и ред.: И. Прохорова ... et. al.] (Новое литературное обозрение. Научное приложение, вып. 76) (Москва: Новое литературное обозрение, 2009), 327-36о.

249. "Московско-тартуская семиотика: ее достижения и ее ограничения," Новое литературное обозрение 98 (2009): 11-26. Available online at: (1) http://magazines.russ.ru/nlo/2009/98/zh5.html

250. "Проблемы формирования русского литературного языка," in Труды Отделения историко-филологических наук, 2007, отв. ред. А. П. Деревянко (М.: Наука, 2009): 53-63.

251. "Архиерейское обещание: эволюция текста в России XV-XVIII веков и проблемы церковной истории,” іп Православное учение о церковных таинствах: материалы V Международной богословской конференции Русской Православной Церкви (Москва, 13-16 ноября 2007 г.) [научный редактор: священник Михаил Желтов], 3 vols. (Москва: Синодалная Библейско-богословская комиссия, 2009), Т.2 (Евхаристия: Богословие. Священство), 365-386.

252. “Язык и стиль А.П. Сумарокова," in Александр Сумароков, Оды торжественныя. Елегии любовныя. [Репринтное воспроизведение сборников 1774 года. Приложение: Редакции и варианты. Дополнения. Комментарии. Статьи]; издание подготовил Роналд Вроон [Ronald Vroon] (М.: ОГИ, 2009), $553-614 .^{118}$

\footnotetext{
"aimed at as general an audience as possible." This edition includes "limited cuts [...], mostly in illustrative examples and extended linguistic analysis." The translator explicitly "assumed that linguists will want to consult the Russian text" (ix).

${ }^{118}$ Re-publication of article listed supra, Part II, no. 218.
} 
253. [Review]: А. С. Герд, Лингвистическая типология древнеславянских текстов (СПб.: Изд-во С.-Петербургского ун-та, 2008), Русский язык в научном освещении 1/17 (2009), 312-314. Available online at:

http://www.ruslang.ru/doc/rjanoi7.pdf

254. [Review]: Максимович К.А. Заповъди свљтыхъ отьць: Латинский пенитенциал VIII в. в церковнославянском переводе: Исследование и текст (М.: Изд-во ПСТГУ, 2008), Русский язык в научном освещении 2/18 (2009): 244249. Available online at: http://www.ruslang.ru/doc/rjano18.pdf

255. “Язык живет своей жизнью” [interview by О. Мартыненко], Наука и религия 11 (2009), 6-9.

256. “Святость и грех" (53.00) [podcast of RFE/RL interview], "С христианской точки зрения” (25 July 2009), редактор и ведущий программы Яков Кротов, Pадио Свобода, URL: http://www.svoboda.org/audio/audio/244871.html.

257. "Ключевое слово этой недели - 'бесчестие”" (4.05) [podcast and transcript of RFE/RL interview conducted by Лиля Пальвелева], Программа "Свобода в полдень" (3 August 2009), ведущая Марина Дубовик, Paдио Cво6ода, URL:http://www.svoboda.org/content/transcript/1790948.html.

258. “Зачем нам нужно знать историю языка?” (41.34) [podcast and transcript of interview conducted by Марина Королева], “Говорим по-русски. Передачаигра" (9 August 2009), Эхо Москвы, URL:

http://www.echo.msk.ru/programs/speakrus/610664-echo.phtml

259. "Русский грех и русское спасение" [Полная стенограмма лекции, прочитанной [...] Виктором Живовым 25 июня 2009 года в клубелитературном кафе Bilingua в рамках проекта «Публичные лекции Полит.ру»], Полит.py (13 August 2009), URL: http://polit.ru/article/2009/o8/13/pokojanije/

26o. "Виктор Живов: нам сейчас как никогда нужна нормализованная орфография" (7:24) [streaming video of TV «интервью "Вестям" ... об опасности либерализации правил орфографии и ... неграмотность политиков»], uploaded by Телеканал Вести (зо ноября 2009), URL: http://my.mail.ru/bk/vesti.ru/video/society/30307.html

2010

261. "Историко-культурные аномалии: проточистилище в иосифлянской традиции," Вестник истории, литературы и искусства 7 (2010): 160-177.

262. "Гуманитарные науки: Чем мы страдаем и как лечиться," пер. с англ. К.В. Бандуровского, in “Десять отзывов на статью Кевина Платта," special section, Новое литературное обозрение 106 (2010): 43-48. Available online at: http://magazines.russ.ru/nlo/2010/106/gu5.html.

263. "Handling Sin in Eighteenth-Century Russia," in Andrew Kahn, ed., Representing Private Lives of the Enlightenment [SVEC 2010:11] (Oxford: Voltaire Foundation, 2010), 123-148. 
264. "Institutionalized Soteriology in the Western and Eastern Churches,"

Slavica Ambrosiana 1 (2010): 51-76. ("Sant' Ambrogio e i santi Cirilli e Metodio: Le radiciGreco-Latine della civiltà slava.” Atti del primo dies academicus, 25-26 maggio 2009. A cura di M.C. Presenti e K. Stantchev).

265. "Между раем и адом: Кто и зачем оказывался там в московской Руси XVI века," Факты и знаки: Исследования по семиотике истории, 2 (2010): 80110.

266. “Несколько дополнительных заметок к статье Б.А. Успенского «Право и религия в Московской Руси»," in Россика/Русистика/Россиеведение, Кн. 1: Язык/История /Культура [ред. коллегия, Е.И. Пивовар (отв. редактор) ... et al.] (М.: Российский гос. гуманитарный университет, 2010), 287-302.

267. "The Myth of the State in the Age of Enlightenment and Its Destruction in Late Eighteenth-Century Russia," translated by Liv Bliss, Russian Studies in History 48:3 (Winter 2009-2010): 10-29. ${ }^{119}$

268. "Moscow-Tartu Semiotics: Achievements and Limitations," translated by Natalya Perova, Social Sciences 41:2 (2010): 35-49. ${ }^{120}$

269. "Aleksii," in The Oxford Dictionary of the Middle Ages, edited by Robert E.

Bjork. 4 vols. (Oxford; New York: Oxford University Press, 2010), 1: 34.

270. "Gennadii (Gonzov), archbishop of Novgorod," ibid., 2: 693.

271. "Hilandar," ibid., 2: 799.

272. "Makarii (Macarius)," ibid., 3:1071-1072.

273. "Maximus the Greek (Michael Trivolis)," ibid., 3: 1107.

274. "Panteleimon," ibid., 3:1251.

275. "Peter, metropolitan of Kiev," ibid., 3:1283.

276. "Philology, Slavic," ibid., 3:1295-1296.

277. "Vladimir (Volodimer) Monomakh," ibid., 4:1709.

278. "Zograph (Mount Athos)," ibid., 4: 1784.

279. [Review]: Протоиерей Георгий Крылов. Книжная справа XVII века.

Богослужебные Минеи (Москва: Индрик, 2009), Русский язык в научном освещении 1/19 (2010): 305-310.

280. "Рождественский вертеп" [transcript of RFE/RL interview], "Ключевое слово" (3 January 2010), ведущая программы Лиля Пальвелева, Радио Свобода, URL:http://www.svoboda.org/content/article/1919857.html .

281. “«усская душа»-- результат провала дисциплинарной революции: о культуре: беседа с заместителем директора Института русского языка имени В. В. Виноградова Российской академии наук Виктором Марковичем Живовым,” записал С. Шаповал, Культура (1 April 2010): 4.

282. "Берестяная грамота как тысячное письмо из средневековья" [transcript of RFE/RL interview], "Время Свободы", редактор и ведущий итоговых

\footnotetext{
${ }^{119}$ Translation of VL 614 (nо. 96), from the version that appeared in Из истории русской культуры, Т. 6: XVIII-начало XIX века (М.: Языки русской культуры, 2000), 657-683, listed supra, Part I, addendum 4, under the entry for 2000.

${ }^{120}$ Translation of 2009 article listed supra, Part II, no. 249.
} 
выпусков программы Андрей Шарый (24 July 2010), Paдио Свобода, URL: http://www.svoboda.org/content/article/2108169.html.

283. “Власть и церковь в XVIII веке” (52.59) [podcast of RFE/RL interview], “C христианской точки зрения” (26 June 2010), редактор и ведущий программы Яков Кротов, Радио Свобода, URL: http://www.svoboda.org/audio/audio/276519.html.

284. “Школа злословия: Виктор Живов,” YоuTube (42:25) [Streaming video of television interview conducted by Tat'iana Tolstaia and Avdot'ia Smirnova], HTB (4 October 2010), uploaded by Авдотья Смирнова (27 July 2012), URL:

www.youtube.com/watch?v=XWqrixgMGkc

285. “Честная бедность: интеллигентский миф или норма жизни в культуре?" (44.04) [streaming video of TV talk-show panel], "Тем временем" с Александром Архангельским (2010), Россия-Культура, URL: http://tvkultura.ru/video/show/brand id/20905/episode id/156066.

2011

286. М.В. Ломоносов, Собрание сочинений в 10-ти томах. Т.VII: Труды по филологии. 1739-1758 г2. Изд. 2-е, исправл. и доп. [отв. ред. В. М. Живов] (М., Наука, 2011).

287. М.В. Ломоносов. Собрание сочинений в 10-ти томах. Т.VIII: Поэзия. Ораторская проза. Надписи. 1738-1764 г2. Изд. 2-е, исправл. и доп. [отв. ред. В. М. Живов] (М., Наука, 2011).

288. "On the Language of the Book of Degrees of the Royal Genealogy," in The Book of Royal Degrees and the Genesis of Russian Historical Consciousness = "Stepennaia kniga tsarskogo rodosloviia" i genezis russkogo istoricheskogo soznaniia, edited by Gail Lenhoff and Ann Kleimola (UCLA Slavic studies; new ser., v. 7) (Bloomington, Ind.: Slavica Publishers, 2011), 141-153.

289. "Позиция причастных оборотов и их дискурсивные свойства в языке русских летописей," Слово и язык: Сборник статей к восьмидесятилетию академика Ю.Д.Апресяна, отв. ред. И.М. Богуславский, Л.Л. Иомдин, Л.П. Крысин (Studia philologica) (Москва: Языки славянских культур, 2011), 473-492. 290. "Сочинительные союзы между причастным оборотом и главным предложением в памятниках восточнославянской письменности,” in Библеистика, славистика, русистика: к 7о-летию заведующего кафедрой библеистики профессора Анатолиа Алексеевича Алексеева [отв. ред. Е. Л. Алексеева] (СПб.: Филологический факультет Санкт-Петербургского гос. унта, 2011), 404-425.

291. "Видения света и проблемы русского средневекового исихазма," in Огонь и свет в сакральном пространстве: материалы международного симпозиума, редактор-составитель А.М. Лидов = Light and fire in the sacred space: materials from the International Symposium, edited by Alexei Lidov (Москва: Индрик, 2011), 37-41. 
292. “Венок на могилу Александра Васильевича Исаченко. К столетию со дня рождения: Письма А.В. Исаченко В.М. Живову,” Русский язык в научном освещении 2/22 (2011): 268-304. Available online at:

http://www.ruslang.ru/doc/rjano22.pdf.

293. (with А.А. Пичхадзе), "Член-корреспондент РАН Александр

Михайлович Молдован (К бо-летию со дня рождения),” Известия РАН, Серия литературы и языка, 70:2 (2011): 69-72

294. [Review]: Борисоглебский сборник. Collectanea borisoglebica. Вып. I / Под ред. Константина Цукермана [Осcasional Monographs, II. Published by the Ukrainian National Committee for Byzantine Studies] (Paris, 2009), Русский язык в научном освещении 2/22 (2011): 316-317. Available online at:

http://www.ruslang.ru/doc/rjano22.pdf.

295. [Review]: О.Н.Киянова. Поздние летописи в истории русского литературного языка: конец XVI-начало XVIII веков (СПб.: Алетейа, 2010), Русский язык в научном освещении 2/22 (2011): 317-319. Available online at: http://www.ruslang.ru/doc/rjano22.pdf.

296. "Русский язык за гранью нервного срыва" (43:18) [streaming video of TV talk-show panel], "Тем временем" с Александром Архангельским (14 February 2011), Россия-Культура, uploaded 18 April 2013, URL:

http://tvkultura.ru/video/show/brand id/20905/episode id/155928/video id/15592 $\underline{8}$

297. “К “Ко создал кириллицу?" (6.30) [podcast and transcript, timed to coincide with the celebration of День славянской письменности (24 Мау)], "Ключевое слово" (29 Мау 2011), ведущая программы Лиля Пальвелева, Радио Свобода, URL: http://www.svoboda.org/audio/audio/312605.html

298. "Летний гуманитарный университет. Гаврила Державин - классик или модернист" (52.59) [podcast and transcript includes Zhivov's comments on Derzhavin], "Классный час", автор и ведущая программы Тамара Ляленкова (7 August 2011), Радио Свобода, URL: http://www.svoboda.org/author/184.html.

\section{2}

299. Эволюция понятий в свете истории русской культуры, отв. ред. В. М. Живов, Ю. В. Кагарлицкий (Studia philologica) (М: Языки славянских культур, 2012).

30o. Boris Uspenskij and Viktor Zhivov, "Tsar and God" and Other Essays in Russian Cultural Semiotics, translated from Russian by Marcus C. Levitt, David Budgen, and Liv Bliss; edited by Marcus C. Levitt (Ars Rossika) (Boston: Academic Studies Press, 2012).

301. “Суеверия и забобоны," in Эволюция понятий в свете истории русской культуры, 130-150. 
302. "Cultural Reforms in Peter I's System of Transformations," in "Tsar and God" and Other Essays in Russian Cultural Semiotics, 191-238. ${ }^{121}$

303. "The Myth of the State in the Age of Enlightenment and Its Destruction in Late Eighteenth-Century Russia," translated by Liv Bliss, in "Tsar and God" and Other Essays in Russian Cultural Semiotics, 239-258. ${ }^{122}$

304. (with B. A. Uspenskij), "Tsar and God: Semiotic Aspects of the Sacralization of the Monarch in Russia," in "Tsar and God" and Other Essays in Russian Cultural Semiotics, $1-112 .{ }^{123}$

305. "О времени и обстоятельствах появления несогласованных кратких действительных причастий (деепричастий) в языке русской письменности,” in От значения к форме, от формы к значению: сборник статей в честь 8олетия члена-корреспондента РАН Александра Владимировича Бондарко [ред. коллегия, М.Д. Воейкова ... (et al.)] (Studia Philologica) (М.: Языки славянских культур, 2012), 179-189.

306. “Лингвистический капитал и его трансформации в истории русского языка последнего столетия," in Русский язык в культурно-историческом измерении. Посвящается гоо-летию Я. К. Грота. Тезисы докладов III Международной конференции «Культура русской речи», отв. ред. А. Д. Шмелев (М.: Институт русского языка им. В. В. Виноградова РАН, 2012), 889o. Available online at:

http://starling.rinet.ru/ sergius/Grotovskaja Konferencija/ThezisyGrotMaket.pdf

307. "Il capitale linguistico e la sue trasformazioni nella storia linguistica del secolo scorso" [translated by Maria Di Salvo], Studi slavistici: Rivista dell'Associazione Italiana degli Slavisti IX (2012): 71-84. URL: http://www.fupress.net/index.php/ss/article/view/12229/11572

3о8. "Об употреблении одной книжной конструкции в памятниках восточнославянской письменности (глагол быти с причастием наст. времени)," in Irina Podtergera, ed., Schnittpunkt Slavistik: Ost und West im wissenschaftlichen Dialog: Festgabe für Helmut Keipert zum 7o. Geburtstag, Teil 3 (Göttingen: V \& R Unipress: Bonn University Press, 2012), 235-249.

309. "Апокалипсис свободы. Заметки об оде 'Вольность' А.Н. Радищева," in Guido Carpi, Lazar Fleishman, and Bianca Sulpasso, eds. Venok: Studia slavica Stefano Garzonio sexagenario oblata. In Honor of Stefano Garzonio (Stanford Slavic Studies, v. 40-41) (Stanford: Department of Slavic Languages and Literatures, Stanford University, 2012), 75-87.

310. “Замечательный литературовед-филолог," in From Medieval Russian Culture to Modernism: Studies in Honor of Ronald Vroon, edited by Lazar

\footnotetext{
${ }^{121}$ Translation of VL 618 (no. 147). See "List of Original Publications," in "Tsar and God," 259.

${ }^{122}$ Re-publication of English translation listed supra, Part II, no. 267. See "List of Original Publications," in "Tsar and God," 259.

${ }^{123}$ Translation of VL 613 (no. 85), from the version in Б. А. Успенский, Избранные труды, $2^{\text {nd }}$ ed., cited supra, Part I, Addendum 3, under the entry for 1996. Cf. "List of Original Publications," in "Tsar and God," 259 .
} 
Fleishman, Aleksandr Ospovat, and Fedor Poljakov (Russkaia kul'tura v Evrope = Russian culture in Europe, v. 8) (Frankfurt am Main: Lang, 2012), 11-13.

311. "Заметки о епитимийниках как источнике по истории русской покаянной дисциплины," in ibid., 15-22.

312. "Два этапа дисциплинарной революции в России XVII и XVIII столетия," Cahiers du monde russe 53:2-3 (2012): 349-374.

313. "Исторический очерк о церковнославянском языке," in А.А. Плетнева, А.Г. Кравецкий, Церковнославянский язык. 5-е изд (М.:АСТ-ПРЕСС Книга, 2012), 9-20.

314. "Mystagogie Maxima Vyznavače a rozvoj byzantské teorie obrazu," translated by Antonín Čížek, Parrésia: Revue pro východní křest’anství 6 (2012): 11$32 .{ }^{124}$

315. [Review]: Ильченко О.С. История категории одушевленности в русском языке (СПб.: Нестор-история, 2011), Русский язык в научном освещении 2/24 (2012): 308-310. Available online at: http://www.ruslang.ru/doc/rjano24.pdf

316. [Review]: Christine Watson, Tradition and Translation: Maciej Stryjkowski's Polish Chronicle in Seventeenth-Century Russian Manuscripts (Uppsala: Acta Universitatis Upsaliensis: Studia Slavica Upsaliensia 46, 2012), Русский язык в научном освещении 2/24 (2012): 319-320. Available online at:

http://www.ruslang.ru/doc/rjano24.pdf

317. "Sin and Salvation in the History of Russian Spirituality," YouTube (52:03) [video of public talk delivered on 22 February 2012 at the Center for Russian, East European, and Eurasian Studies at the University of Michigan], uploaded by umcrees (5 March 2012), URL: www.youtube.com/watch?v=wz2NzdLDa5E

318. "Модернизацией по культуре" [streaming video of TV interview], Угол зрения с Александром Приваловым (1 June 2012), YouTube (25:51), uploaded ExpertTVOnline (4 June 2012), URL: www.youtube.com/watch?v=WszxyUx $5 \mathrm{~h} 7 \mathrm{w}$; transcript available on ЭксnеpmOnline: http://expert.ru/2012/o6/1/ugol-zreniya/

319. “Святость и свинство” (52.59) [podcast of RFE/RL interview, conducted the day after the verdict against Pussy Riot. The formal topic of discussion is N. A. Berdyaev's quip: 'Русский человек живет крайностями - либо святость либо свинство.' Что сие означает и справедливы ли эти слова сегодня?], “С христианской точки зрения” (18 August 2012), редактор и ведущий программы Яков Кротов, Радио Свобода, URL: http://www.svoboda.org/audio/audio/373561.html.

320. "Виктор Маркович Живов о лекции А.А. Зализняка [28 сентября 2012 года. МГУ]," YouTube (о:50), uploaded by Natalia Demina (28 September 2012), URL: www.youtube.com/watch?v=s8aHhbXwEL4

321. "[Sin and Salvation in the History of Russian Spirituality; respondent: Serge Ruzer (The Hebrew University)]" YouTube (126:51) [video of public talk delivered at the Open meeting of the Institute of Advanced Studies Research Group "Cultural

${ }^{124}$ A Czech-language translation of $V L 611$ (no. 6o) from $V L 621$ (no. 180). See Parrésia 6 (2012), $11 n .1$. 
Archaeology of Jews and Slavs: Medieval and Early Modern Judeo-Slavic Interaction and Cross Fertilization," co-sponsored by the Department of Russian and East European Studies at the Hebrew University of Jerusalem], uploaded by Denis Dorum (4 November 2012), URL: www.youtube.com/watch?v=yxk4EbGZ9QY

322. "14 лет спустя: Гуманитарное образование в России и США," подготовила Наталья Кулинка, МОСТ-The Bridge: Журнал Международной Ассоциации Гуманитариев, Volume 1, Issue 1-2 (November 2012), URL: http://thebridge-moct.org/volume-1-issue-1-2-1-2\%Do\%BD\%Do\%BE\%Di\%8F\%Do\%B1\%Di\%80\%D1\%8C-2012-9/.

323. "Victor Zhivov at TEDxSkolkovo," YouTube (20:34) [video of a talk on “Языковой стандарт," delivered December 2012, in Moscow, Russia, at the Open University, Skolkovo], uploaded by TEDx Talks (25 January 2013), URL: www.youtube.com/watch?v=qeM4UIf-g1s

324. “П “Профессор должен быть привлекательным для студентов': Профессор Калифорнийского университета, замдиректора Института русского языка РАН Виктор Маркович ЖИВОВ - об интеллектуальной честности, гуманитарном образовании, истории представлений о кощунстве и дисциплинарных революциях" [interview conducted by Людмила Жукова], Booknik (3 December 2012), URL: http://booknik.ru/today/faces/zhivov/

\section{3}

325. "Видение света и проблемы русского средневекового исихазма," in Иеротопия огня света в культуре византийского мира, редактор-составитель A.М. Лидов = Hierotopy of Light and Fire in the Culture of the Byzantine World, ed. Alexei Lidov (М.: “Феория," 2013), 350-367.

326. "Заметки о категории одушевленности в стандартном церковнославянском," in Slavica Svetlanica: язык и картина мира: к юбилею Светланы Михайловны Толстой [редкол.: А. В. Гура, О. В. Белова, Е. Л. Березович] (М.: Индрик, 2013), 42-55.

327. "Порядок слов при verba dicendi в восточнославянских памятниках письменности," in Славянское языкознание: XV Международный съезд славистов: Минск, 21-27 августа 2013 г.: доклады российской делегации [ответственные редакторы А.М. Молдован, С.М. Толстая] (М.: Индрик, 2013), $331-363$.

328. "Two Images of Constantine the Great in Russian Historical Writings of the Fifteenth - Eighteenth centuries," in La figura di Costantino imperatore e l'ideologia imperiale nella storia culturale, religiosa, civile dei paesi slavi, a cura di Francesco Braschi, Maria Di Salvo (Slavica Ambrosiana, 4) (Milano: Biblioteca Ambrosiana; Roma: Bulzoni, 2013), 141-168.

329. "Книжная справа," in Большая российская энциклопедия [научноредакционный совет, председатель Ю.С. Осипов] (М.: Научное издательство "Большая российская энциклопедия," 2004-), Т. 14. (Киреев--Конго), 337. 
330. “Архаисты и новаторы," in Школьный энциклопедический словарь «Русский язык» [Сергей Монахов, Дмитрий Чердаков, et. al.; дизайн: Ждан Филиппов] (СПб: Санкт-Петербургский гос. ун-т, 2013). Available for download on iOS devices at: http://rusdictionary.ru

331. "Аполлос Байбаков," ibid.

332. "Барсов А.А.," ibid.

333. “деловой (приказный) язык," ibid.

334. "История русского литературного языка," ibid.

335. "Карамзин H.M.," ibid.

336. “книжная справа," ibid.

337. “книжное (литургическое) произношение," ibid.

338. “Ломоносов M.B.," ibid., 174-175. Available online at:

http://rusdictionary.ru/docs/Dictionary--159--175.pdf

339. "нормализация русского литературного языка," ibid.

340. "Петр I (форма языка)," ibid.

341. "простой язык," ibid.

342. "Пушкин А.C.," ibid.

343. “Склады (чтение по)," ibid.

344. "Сумароков А.П.," ibid.

345. “Шишков А.С.," ibid.

346. “Литература в школе: что готовит нам новый стандарт?” (43:53)

[streaming video of TV talk-show panel], "Тем временем" с Александром

Архангельским (28 January 2013)], Россия-Культура, URL:

http://tvkultura.ru/video/show/brand id/20905/episode id/215264

347. "В. М. Живов," YouTube (13.42) [streaming video of interview addressing the following questions: (1) Справедливо ли суждение Н. С. Трубецкого о русском языке: "Сопряжение церковнославянской и великорусской стихий ставит этот язык в совершенно исключительное положение?”; (2) Почему сегодня так популярны спекуляции на тему “Все языки мира произошли от русского”? (3) “Поиски национальной идеи превращаются в филологическую проблему?”; (4) “Чем Вам интереснее заниматься в лингвистике?”; (5) “Почему в русском языке распалась система индоевропейских прошедших времен, сохранившаяся в английском, французском, немецком?”; (6) “Почему лингвисты отказываются отвечать на вопрос 'почему'?”]," uploaded by Энциклопедический словарь (2о February 2013), URL: http://www.youtube.com/watch?v=kJ5VXaRZpw4 ${ }^{125}$

348. “Виктор Маркович Живов," YоuTube (91:41) [video of extended and wideranging personal interview, conducted in Zhivov's Moscow apartment by Tat'iana

\footnotetext{
125 The YouTube $<$ http://www.youtube.com/user/ruslang4school/about> "является своего рода приложением к школьному энциклопедическому словарю "Русский язык", подготовленному в СПбГУ (СПб., 2013). В видеоприложении содержатся такие комментарии к отдельным статьям словаря, которые показывают, как известные ученые, писатели, педагоги относятся к тем или иным лингвистическим идеям, освещаемым в данном издании."
} 
Kuchinko], uploaded by pravmir (4 April, 2013), URL: www.youtube.com/watch?v=JGoo7XTvHxo

349. Татьяна Кучинко, "Виктор Живов о Евангелии в советских хрестоматиях, неофитстве и симпатичных 90-х,” Pravmir.ru: Православие и мир: Ежедневное интернет-издание о том, как быть православным сегодня (17 April 2013), with photos by Julia Makoveychuk. URL:

http://www.pravmir.ru/viktor-zhivov-o-literaturnyx-biografiyax-evangelii-vsovetskix-xrestomatiyax-i-simpatichnyx-9o-x-foto-video/\#ixzzzvUTtQXr5

350. “Виктор Живов: Византия не виновата," записал Дмитрий Ребров, Нескучный сад: Журнал о православной жизни (18 April 2013), URL: http://www.nsad.ru/articles/viktor-zhivov-vizantiya-ne-vinovata?print=1.

351. “С точки зрения вечности...” [interview “об особенностях русской государственности,” conducted by Руслан Хестанов, Ольга Андреева; фото Алексей Майшев], Русский Pепортёр 3:82 (19 April 2013), URL: http://rusrep.ru/2009/o3/interview zhivov/

352. "Интервью с Виктором Живовым," МОСТ-The Bridge: Журнал Международной Ассоциации Гуманитариев, Volume 2, Issue 4 (7) (April-May 2013), URL: http://thebridge-moct.org/volume-2-issue-4-7\%Do\%Bo\%Do\%BF\%D1\%80\%Do\%B5\%Do\%BB\%Di\%8C\%Do\%BC\%Do\%Bo\%Do\%B9-2013/. ${ }^{126}$

\section{4}

353. "Das Kirchenslavische bei den Ostslaven" [translated by Sergej Illger and Tilman Berger], in Die slavischen Sprachen: Ein internationales Handbuch zu ihrer Struktur, ihrer Geschichte und ihrer Erforschung. Herausgegeben von Sebastian Kempgen ... [et al.] = The Slavic languages: an international handbook of their structure, their history and their investigation, edited by Sebastian Kempgen ... [et al.] (Handbücher zur Sprach- und Kommunikationswissenschaft, Bd. 32), 2 vols. (Berlin: Walter de Gruyter, 2009-2014), v. 2 (2014): 1276 -1294.

354. Viktor Zhivov, "Conceptual History, Cultural History, Social History," trans. by Boris Maslov, Вивліоөика: E-Journal of Eighteenth-Century Russian Studies, Vol. $2(2014): 1-14 \cdot{ }^{127}$

${ }^{126}$ Transcript of an audio interview conducted in the winter of 2012/2013 by Наталья Кулинка and intended as a follow-up to a previously-published interview with Zhivov (supra, Part II, no. 322).

${ }^{127}$ Translation of item listed supra, Part II, no. 243. 